Portland State University

PDXScholar

$11-1-1994$

\title{
The Tumult of Amboise and the Importance of Historical Memory in Sixteenth-Century France
}

Trevor Charles Schmitz-Thursam

Portland State University

Follow this and additional works at: https://pdxscholar.library.pdx.edu/open_access_etds

Part of the History Commons

Let us know how access to this document benefits you.

\section{Recommended Citation}

Schmitz-Thursam, Trevor Charles, "The Tumult of Amboise and the Importance of Historical Memory in Sixteenth-Century France" (1994). Dissertations and Theses. Paper 4789.

https://doi.org/10.15760/etd.6673

This Thesis is brought to you for free and open access. It has been accepted for inclusion in Dissertations and Theses by an authorized administrator of PDXScholar. Please contact us if we can make this document more accessible: pdxscholar@pdx.edu. 


\section{THESIS APPROVAL}

The abstract and thesis of Trevor Charles Schmitz-Thursam for the Master of Arts in

History were presented November 1,1994 , and accepted by the thesis committee and the department.

COMMITTEE APPROVALS:

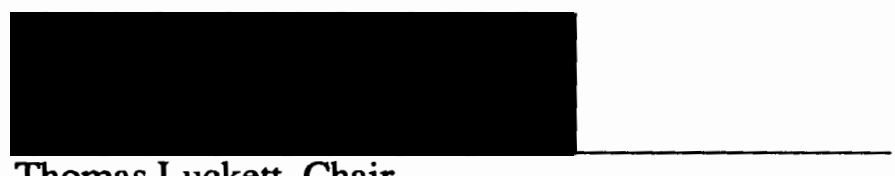

Thomas Luckett, Chair
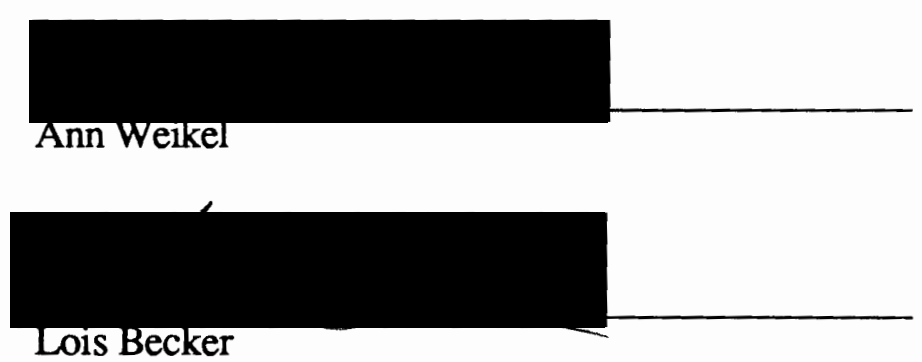

DEPARTMENT APPROVAL:

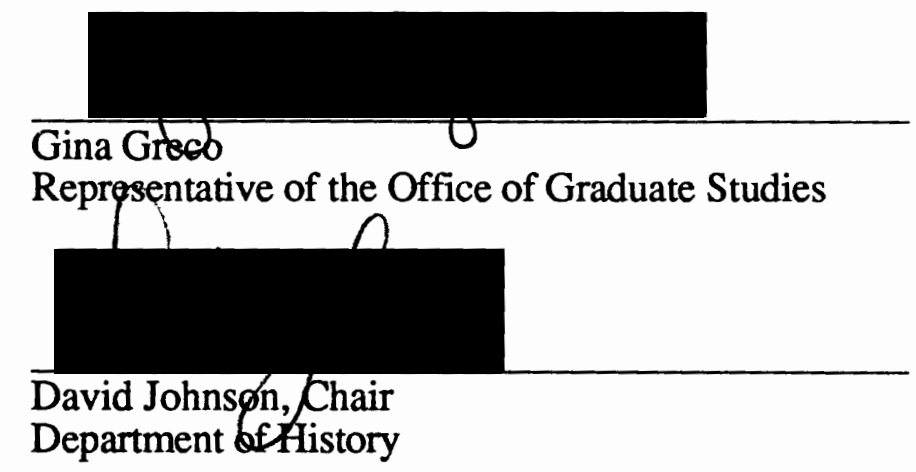

\section{ACCEPTED FOR PORTLAND STATE UNIVERSITY BY THE LIBRARY}

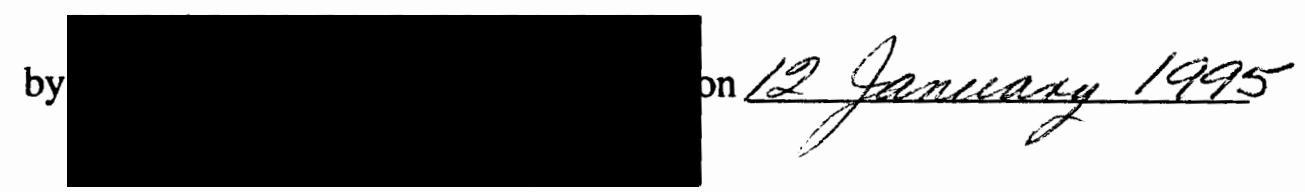




\begin{abstract}
An abstract of the thesis of Trevor Charles Schmitz-Thursam for the Master of Arts in History presented on November 1, 1994.
\end{abstract}

Title: The Tumult of Amboise and the Importance of Historical Memory in SixteenthCentury France.

Humanist legal scholarship was the catalyst to historical revolution that took place in sixteenth-century France. French philologists succeeded in demonstrating the cultural distinctiveness of France from a heretofore assumed classical heritage shared with ancient Rome. As a result, scholars sought to retrace the historical origins of France in the non-Roman Gauls and Franks. Their intensive study of the laws, customs and institutions that developed in France, as distinct from ancient Rome, transformed the understanding of the national past.

Following the introduction of the principles of historical anachronism and cultural relativism, the sixteenth century witnessed a transformation of traditional perceptions of historical time. It was during this period when the historical myths, legends and traditions that comprised the cultural fabric of French society were called into question, were transformed, and emerged as new myths that spoke more directly to the crises of the French Religious Wars.

The purpose of this study is to attach greater significance to the Tumult of Amboise of 1560 than has previously been afforded in the scholarship of this period. The Tumult of Amboise provide not only the impetus for the civil wars that 
were waged in France for nearly half a century, but also served as the catalyst for an first expression of Protestant resistance theory that was to change the face of political discourse in this period. The debate centered around the Tumult of Amboise set the stage for constitutional theories regarding the laws of succession and the role of the Estates-General that were dominate political discourse in the latter half of the sixteenth century.

As political polemicists increasingly sought to reconstruct an image of the mythical French past, in order to demonstrate the ancientness of the French constitution, the historical fiction that developed around these efforts became a functioning political ideology that should be viewed as one of the first concerted expressions of French nationalism. In this regard, the recreation of the national past took on a patriotic dimension heretofore absent from traditional, chroniclestyled medieval histories and, in time, developed into a uniquely Gallican mythology that stood defiantly as a rival to the cultural heterodoxy of Rome.

Further, the purpose of this study is to demonstrate the developmental nature of political discourse in this period. As the civil wars progressed, doctrines of constitutionalism and limited monarchy began to be laced with more abstract theories regarding the nature of political obligation and the responsibility of the ruler to his subjects. Employing a comparative analysis of discourse from the 1560's to the succession of Henri IV, it will be shown that the transformation of political propaganda was directly dependent on the historical memory of the participants, who engaged in an effort to frame the political and religious crises within the context of their perceptions of the past. 
THE TUMULT OF AMBOISE AND THE IMPORTANCE OF HISTORICAL MEMORY IN SIXTEENTH-CENTURY FRANCE

by

TREVOR CHARLES SCHMITZ-THURSAM

A thesis submitted in partial fulfillment of the requirements for the degree of

\author{
MASTER OF ARTS \\ in \\ HISTORY
}

PORTLAND STATE UNIVERSITY

1994 
TABLE OF CONTENTS

PAGE

INTRODUCTION .........................................................

\section{CHAPTER}

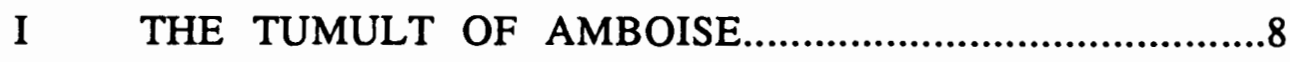

II HISTORY AND THE REVOLUTION IN PRINT .................16

III HISTORY AND THE START OF THE CIVIL WARS.................21

IV DEVELOPMENT OF AN IDEOLOGY .........................32

$\mathrm{V} \quad$ HISTORY AND NATIONALISM.............................42

VI SCHOLARSHIP GIVES WAY TO POLEMIC....................53

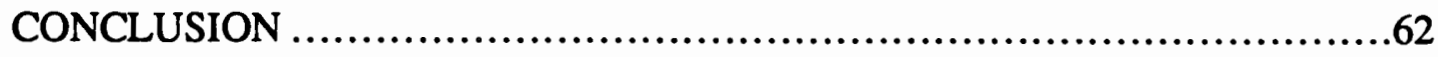

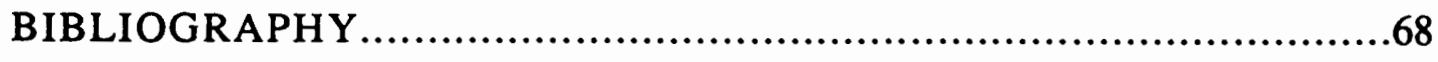




\section{INTRODUCTION}

Analyzing the resurrection of Ponocrates in Rabelais' Gargantua, Richard Berrong notes how the narrator purposefully attempts to portray himself as a modern historiographer-that is, as one who engages in scientific research; as opposed to chroniclers, who simply retell old stories. ${ }^{1}$ Ponocrates' efforts are significant in that they reflect the changes in the intellectual and cultural milieu taking place in France throughout the course of the sixteenth century. The Renaissance and the rise in humanist learning and scholarship significantly altered the way in which European society reflected on its past.

Humanist legal scholarship should be seen as the catalyst to the "historical revolution" that took place in sixteenth-century France. When French philologists undertook a study of the body of Roman law, the distinctiveness of French culture-feudal and scholastic rather than classical-became clear. Through their study, proponents of the mos gallicus undermined the universality of Roman law. In so doing, the laws of Rome came to be viewed as the laws of a past society, a society with institutions and customs which were dissimilar to those of France. Further, it came to be believed that these laws failed to hold normative standards which could be readily applied to present circumstances. As a result, scholars began to retrace the historical origins of France, looking to the nonRoman Gauls and Franks as the peoples who, together, came to constitute the ancient French "state." Their efforts spearheaded what could arguably be considered an "historical revolution." That is, the intensive study of the laws, customs, and institutions that developed in France, as distinct from those of ancient Rome, transformed the understanding of the national past.

1 Richard Berrong, Rabelais and Bakhtin: Popular Culture in Gargantua and Pantagruel (Lincoln, NE: University of Nebraska Press, 1991), 41-2. 
Furthermore, this new type of humanist scholarship "demonstrated the relativity of laws and institutions, undermining the notion of normative standards derived from antiquity." 2 Up to this point, history was viewed primarily as monolithic. The Renaissance and Reformation shattered that notion forever. Coupled with the work of Protestant scholars, who were engaged in an effort to reconstitute the origins of the "primitive church" in order to chart the decline of its institutions, humanist scholarship succeeded in asserting the cultural distinctiveness of France from a heretofore assumed classical heritage. Together these endeavors revitalized a world view that had been taken for granted. The reality of European society was forever altered by the introduction of the principle of relativism and, though it will be argued, not fully developed in this period, the employment of a diachronic view of history. In contrasting phenomena between different time periods and contemporary cultures and, more importantly, by providing an understanding of the importance of cultural context, humanist rationalism and empiricism transformed traditional perceptions of historical time. As a result, an effort was made to impose some sense of order on a traditional world view tumed upside-down by historical relativism.

It is the goal here to provide an understanding of the intellectual efforts of a society, in this period of rapid change and turmoil, that was seeking to construct an image of the past that would serve to provide some context and support to its present circumstances. During the sixteenth century the historical myths, legends, and traditions that comprised the cultural fabric of French society were called into question, were transformed, and emerged as new myths that spoke more directly to contemporary events. Traditional societies tend to hold to a view of the past as monolithic and immobile. As a result, these societies are

2 Zachary S. Schiffman, "Humanism and the Problem of Relativism," in Humanism in Crisis: The Decline of the French Renaissance, ed. Philippe Desan (Ann Arbor: University of Michigan Press, 1991), 70. 
built around, and adhere to, customs and traditions that reinforce the immemorial character of institutions, practices, and laws. The social, religious, and political upheaval witnessed in France during this period called these traditions and customs into question. Eric Hobsbawm argued that "when social change accelerates or transforms [a] society beyond a certain point, the past must cease to be the pattern of the present, and can at best become the model for it." Such was the case for sixteenth-century France. In response to acute social change, humanist scholarship succeeded in creating and popularizing an image of a mythical past that, when contrasted with the tumultuous present, in effect served as an intellectual anesthetic.

The questioning and reconstruction of tradition and custom, in the temporal as well as spiritual realm, was born of humanist scholarship, given meaning in the Reformation, and was given expression in the revolution made possible by the printing press. As the number of printed works increased in the course of the sixteenth century, "scattered attacks on one authority by those who favored another provided ammunition for a wholesale assault on all received opinion." One of Montaigne's primary objections to the Reformation was that "private" objections had been brought into a "public" forum. He argued that "[the Reformers] shake off as a tyrannical yoke all the impressions they once had received from the authority of the laws or the reverence of ancient usage...determined from then on to accept nothing to which they have not applied their judgment and granted their consent." 5 This rejection—or at least re-evaluation—of tradition, through the

${ }^{3}$ E.J. Hobsbawm, "The Social Functions of the Past: Some Questions," Past and Present, 55 (1972): 6.

${ }^{4}$ Elizabeth Eisenstein, The Printing Press as an Agent of Change: Communications and Cultural Transformations in Early-Modern Europe, 2 vols. (Cambridge: Cambridge University Press, 1979), vol. I: 125.

5 Michel de Montaigne, Complete Works, trans. Donald Frame (Stanford: Stanford University Press, 1957), 320. 
reflection of individual conscience, underscores the conflict of world views one finds in the sixteenth century: a belief in the all-encompassing authority of the political body, with a belief that "“within' subjectivity [can be found] some bases on which to construct a new order."6

The debate surrounding the construction of this "new order" took place at all levels of French society. In the sixteenth century a traditional, predominantly illiterate, oral culture came to terms with an intellectual revolution taking place-at least on its facewithin an elite, literate culture. One of the goals of this paper will be to illuminate the extent to which there was affinity between "high" and "low" culture. It will be made clear that, indeed, all strata of French society in this period were questioning and redefining their conceptions of the role and process history played in shaping the present. Where humanist scholarship had transformed the historical perception of elites, so too that change of perception was taking place at a popular level. It will be argued that the primary catalyst to this change of perception-printed text-enhanced and strengthened the culture of elites, as well as the menu peuple, because "it added both to their realism and to the richness of their dreams, both to their self respect and to their ability to criticize themselves and others." 7

As the debates taking place within elite circles transformed historical myth and legend, it will be shown that a re-evaluation of the historical past was also taking place at the level of popular culture. At both levels, the effort to recreate the past can be seen, in part, as a longing to somehow reclaim rights or freedoms that were perceived to have been lost over time. In much of the literature of the period, one can detect a shift in the metaphor

${ }^{6}$ François Rigolot, "Writing the Crisis Differently: Ronsard's Discours and Montaigne's Essais," in Humanism in Crisis: The Decline of the French Renaissance, ed. Philippe Desan (Ann Arbor: University of Michigan Press, 1991), 118.

7 Natalie Zemon Davis, Society and Culture in Early Modern France (Stanford: Stanford University Press, 1975), 225. 
"new world" from a geographical to a social context. This literature chronicles a desire, indeed a concerted effort, to reach far back into antiquity in the hope of rediscovering the mythical tales that spoke of a golden age of prosperity. In striving to reclaim the mythic past an "image of a more just society was consciously projected into a non-eschatological future. It wasn't the Son of Man high up in the clouds, but...[men] who, through their struggle, would have to be the bearers of this 'new world'."8

It will be made clear that the struggle to return to this mythical past did not necessitate an understanding of historical change as an ongoing process of development. Furthermore, it will be shown that shared ethical and religious value systems within a culture shape the ways in which that culture understands and relates to its own customs and traditions. The literature of this period blurred the line between history and imagination. The stories that came out the medieval period, stories which supported the perception that fables might provide a moral philosophy by teaching by example, confronted the "histories" of the Renaissance. For the average reader, however, it did not really matter whether the legends were true or not. It was not the truth, but what the story meant to him that mattered. These stories served as a type of living mythology that "appealed directly to a people finding its way through a period of confusing change and therefore much in need of the kind of self image that depended on historical perspective." between fact and fiction, history and narrative, was manifest in the historical debates that took place in the sixteenth century. In underscoring the effort to reclaim and reconstitute the immemorial institutions of the French state, this paper will seek to examine the

8 Carlo Ginzburg, The Cheese and the Worms: The Cosmos of a Sixteenth-Century Miller, trans. John and Anne Tedeschi (Baltimore: Johns Hopkins University Press, 1980), 77-78.

9 Arthur B. Ferguson, Utter Antiquity: Perceptions of Prehistory in Renaissance England (Durham, NC: Duke University Press, 1993), 115-116. 
historical fiction that developed around the origin of these institutions, and the ways in which the uses, or misuses of history transformed political discourse and culture.

Politics is about making claims. Political culture is the field in which these claims are made manifest and, through discourse and symbolic practices, "constitutes the meanings of the terms in which these claims are framed, the nature of the contexts to which they pertain, and the authority of the principles according to which they are binding."10 Taking center stage in the political arena, competing groups mobilize in an effort to control the nature of social and political discourse, attempting to frame the political contest within their own pre-existing social realities. This discourse can be found not only in political rhetoric, but in the rituals, oral traditions, iconography and literary expressions that form the very fabric of the culture in which these political contests take form.

The historian seeking to examine the nature of political discourse for a given period must bear in mind a set of important questions that must be addressed, in order to provide meaning to his findings. A study of discourse, first and foremost, involves the examination of the rules that limit and form the sayable, as defined by a given society at a given time. That study should seek to examine what parts of discourse remain, what becomes part of memory, and what parts disappear in the course of the period under investigation. How does memory appear and affect changes in the relationship between past and present discourse? How does memory validate or reject discursive formations? How is that discourse institutionalized, controlled? Who has access to certain types of discourse? To a lesser or greater extent these questions will be raised and addressed in the course of this paper. The methodological approach employed here will draw upon a variety

10 Keith Michael Baker, Inventing the French Revolution: Essays on the French Political Culture in the Eighteenth Century (Cambridge: Cambridge University Press, 1990), 4. 
of analytic tools and disciplines in seeking to confront the aforementioned questions. ${ }^{11}$ One of the primary goals of this paper will be to underscore the importance of cultural context in constructing discursive formation. To this end, Michel Foucault's efforts to relate discourse "not to a thought, mind or subject which engendered it, but to the practical field in which it is deployed" serve as a particularly useful guide. ${ }^{12}$

11 For further reading related to the methodology employed here, see: Robert Canary and Henry Kozicki, eds, The Writing of History: Literary Form and Historical Understanding (Madison, WI: University of Wisconsin Press, 1978); Michel Foucault, The Archeology of Knowledge, trans. Allen Sheridan Smith (New York: Harper and Row, 1972); Clifford Geertz, The Interpretation of Cultures (New York: Basic Books, 1973); Maurice Halbwachs, On Collective Memory, trans. Lewis A. Coser (Chicago: University of Chicago Press, 1992); Quentin Skinner, The Foundations of Modern Political Thought, 2 vols. (Cambridge: Cambridge University Press, 1978).

12 Michel Foucault, "Politics and the Study of Discourse," in The Foucault Effect: Studies in Governmentality, with two lectures and an interview with Michel Foucault, ed. Graham Burchell, Colin Gordon, and Peter Miller (Chicago: University of Chicago Press, 1991), 60-61. 


\section{CHAPTER 1}

\section{THE TUMULT OF AMBOISE}

When the Reformation exploded in Europe, it inherited a world shaped by a mature humanism that had moved beyond simple devotion to rhetorical and textual eloquence to an inspired search for "truth" in history. As a result, the first generation of reformers could not help but be influenced by an intellectual culture that increasingly sought this truth through the search for evidence and the conquest of historical anachronism. The early endeavors of the reformers, the challenging of the ecclesiastical traditions of the Church, were primarily historical. They sought to revive the true spirit and voice of the "primitive church" and its founders through a examination of the history of the institutions of the Church. Though the "original Protestant vision was of a society of religiously enlightened laymen who were no longer burdened by traditional superstition and tyranny,"13 soon the Reformation entailed much more than doctrinal disputations on ecclesiastical reform. The second generation of Protestant reformers greatly extended the field and concept of the Reformation. As a result, Protestant humanists, at mid-century, moved the debate beyond an indictment of ecclesiastical comuption and impiety. In time, they advanced the course of the Reformation with "executive machinery and a magistrature armed with legal rights against the monarchy itself."14

In the sixteenth century, religion and politics were inexorably linked. In his General History of the Reformation of the Church, the Protestant humanist, Johann

13 Steven E. Ozment, The Reformation in the Cities: The Appeal of Protestantism to Sixteenth-Century Germany and Switzerland (New Haven: Yale University Press, 1975), 164.

14 A.G. Dickens and John Tonkin, eds., The Reformation in Historical Thought (Cambridge, MA: Harvard University Press, 1985), 77. 
Sleidan, commented that "[he] could not omit what concerned the civil government, because, as [he has] already said, they are interwoven each with the other, especially in our times, so that it was not possible to separate them."15 The death of Henri II in 1559, in a jousting accident during a celebration held in honor of the signing of the Treaty of CatesuCambrésis between the warring Habsburgs and Valois, resulted in the seizure of the French throne by the ultra-Catholic Guise faction. Henri II's death marked a turning point for the Reformation in France.

French Protestantism, like its German counterpart, found its strength among the urban middle and upper classes. The greatest number of converts to the Genevan faith came from within the artisan and merchant classes in the towns of the southeast, the Loire Valley, Normandy, and the western coast. From Geneva, Calvin had also succeeded in winning the support of many of France's oldest and most influential families of the noblesse-indeed, much of Calvin's success lay with ability to gain a loyal following among noble women. ${ }^{16}$ Through an elaborate system of clientage and patronage, these powerful families exercised a great deal of influence on the rural nobility. ${ }^{17}$ By midcentury, this network of loyal adherents to the Genevan faith had transformed the French

15 Johann Sleidan, Apology for His History, in Versions of History from Antiquity to the Enlightenment, ed. Donald Kelley (New Haven: Yale University Press, 1991), 327.

16 For more on Calvin's influence upon, and the Protestant careers of, noblewomen, see: Nancy L. Roelker, Queen of Navarre: Jeanne d'Albret, 1528-1572 (Cambridge, MA: Harvard University Press, 1968) and "The Appeal of Calvinism to French Noblewomen in the Sixteenth Century," Journal of Interdisciplinary History, 2 (1972): 391-418.

17 For further background on patronage in the sixteenth century, see: Barbara Diefendorf, Paris City Councilors in the Sixteenth Century: The Politics of Patrimony (Princeton: Princeton University Press, 1983); Robert R. Harding, Anatomy of a Power Elite: The Provincial Governors of Early Modern France (New Haven: Yale University Press, 1978); Sharon Kettering, "Patronage in Early Modern France," French Historical Studies, 17 (Fall, 1992): 839-862; Roland Mousnier, La Vénalité des offices sous Henri IV et Louis XIII, 2nd ed. (New York: Columbia University Press, 1971); Kristen B. Neuschel, Word of Honor: Interpreting Noble Culture in Sixteenth-Century France (Ithaca: Cornell University Press, 1989). 
Protestant churches into a powerful political faction led by two Bourbon princes, Antoine de Navarre and Louis de Condé. With the support of the powerful Châtillon family, Navarre and Condé- ancestors of the god-king, St. Louis (a point to which we will return in due course)-gained a sizable following within the Calvinist wing of the rural noblesse. It has been argued that "the clientage system was the greatest organizational element in this process, followed by the appeal of the Calvinist churches to the nobility to protect theman appeal that provided local factions with immediate military recruiting grounds."18

Though the Protestants had succeeded in gaining a foothold in towns throughout France, the Parlement of Paris and the provincial courts remained strongly opposed to allowing for any measure of religious dissent. The burning of the Protestant Anne du Bourg in December of 1559, a nephew of the former chancellor and an influential member of the Parlement of Paris, signaled the beginning of a policy of religious persecution within the ranks of the parlementaires; a policy that many had suspected would succeed the signing of the treaty ending the Habsburg-Valois war.

A fervent spirit of anticlericalism within the lesser nobility also attracted many converts, for material as well as theological reasons, to the Protestant party. The control of benefices by the noblesse and the wealth of the upper clergy earned the contempt of many of the rural petty nobility. At a meeting of the regional estates in 1560 , the nobility and the third estate called for the confiscation of clerical property in order to meet the king's war debts, a move that would thereby reduce tax obligations. The following year, a meeting of the national Estates-General at Pontoise also ratified a proposal calling for the confiscation of all clerical property.

18 J.H.M. Salmon, Society in Crisis: France in the Sixteenth Century (London: Methuen, 1975), 123-124. 
Against the backdrop of anticlerical ardor, the Tumult of Amboise provided the impetus to the religious wars that were to tear France apart for nearly half a century. Since the death of Henri II, control of the French government lay in the hands of an ultra-Catholic regency dominated by François de Guise and the cardinal of Lorraine, uncles of Francis II's wife, Mary queen of Scots. In 1560 a Protestant nobleman, Jean du Barry, seigneur de la Renaudie, began devising a plot to kidnap the fifteen year-old king; a plot, it was believed, that would succeed in undermining the power of the Guise faction. As La Renaudie and his men met in Amboise and prepared their insurgency against the royal court, the Guises received advanced warning of the imminent coup. The plot was still-born and the Guises captured and executed La Renaudie and several hundred of his followers. Though La Renaudie received no direct backing from the French consistories or from Geneva, the leaders of the Protestant party were almost certainly aware of the plot.

In the wake of the thwarted coup, a war of words erupted between the supporters of the Guises, who denounced the plot as a clear act of treason, and Protestant apologists who were able to offer ostensible justification for La Renaudie's actions. It was in this heated propaganda campaign that the term "Huguenot" was first coined. 19 Protestant justification of the actions of $\mathrm{La}$ Renaudie and his followers marked the first ripple in the wave of Huguenot propaganda that was to flow through France, and much of Europe, in the coming years. The fears of the Huguenot party were reflected in the justificatory stance taken in support of La Renaudie's actions. Of greater importance for our purposes, the line of argumentation employed in the propaganda campaign connected with the Amboise conspiracy can be seen as the first concerted expression of Huguenot resistance theory.

19 Janet G. Gray, "The Origin of the Word Huguenot," Sixteenth Century Journal, 14 (1983): 349-359. 
One of the leading contributors to the body of Protestant polemic that emerged out of the Amboise conspiracy, and changed the face of political discourse in this period, was François Hotman. ${ }^{20}$ Son of Pierre Hotman, an ardent Catholic and conseiller in the Parlement of Paris, François began his legal education at the age of fifteen at the University of Orléans, which by that time had become something of a Mecca for humanist scholarsCalvin himself gained his law degree at the University in 1531 before he began writing his commentaries on Senecca. ${ }^{21}$ In the years prior to Hotman's arrival, Pierre de l'Etoile, a biblical humanist and professor of Roman law at the University of Orléans, had undertaken a legal exegesis of the medieval codifiers of Justian's corpus juris. Through an examination and comparative analysis of the glosses, L'Etoile and his followers found that the commentators had failed to maintain consistent historical context through their employment of aspects of law from a variety of ages in the history of Roman civilization. Moreover, they found that the codifiers had adapted parts of Byzantine and Roman law texts to their medieval society; a practice that was condemned as anachronistic. During his tenure at the University of Orléans, and influenced by the contacts he made upon his return to Paris in 1540, Hotman's humanist training and experience in the "fields of customary law, the techniques of historical exegesis, and the synthetic reconstruction of jurisprudence" 22 proved to be a ready resource for the Huguenot party in the coming years.

${ }^{20}$ For a comprehensive treatment of Hotman's career and writings, see: Ralph E. Giesey, "When and Why Hotman Wrote the Francogallia," Bibliotheque d' Humanisme et Renaissance, 29 (1967): 581-611; Donald Kelley, François Hotman: A Revolutionary Ordeal (Princeton: Princeton University Press, 1973); François Hotman, Francogallia, Latin text by Ralph E. Giesey, trans. J.H.M. Salmon (Cambridge: Cambridge University Press, 1972).

21 Harro Höpfl, The Christian Polity of John Calvin (Cambridge: Cambridge University Press, 1982), 5.

22 François Hotman, Francogallia, Latin text by Ralph Giesey, trans. J.H.M. Salmon (Cambridge: Cambridge University Press, 1972), 10. 
Hotman's link to the Protestant party was solidified when he, rebelling against the involvement of his father in the persecution of Protestants while a member of the Parlement of Paris, left Paris for Lyon in 1548. From Lyon, Hotman lived for a time in Lausanne before settling in Geneva later that year. While living in exile in Geneva, Hotman became an ardent supporter of Calvin and established a close relationship with Théodore de Bèze, who was a student at the law school of the University of Orleans during Hotman's tenure there. After the outbreak of the religious wars, the friendship and working partnership that had been formed between Bèze and Hotman became the wellspring of some of that century's most virulent criticism of the French monarchy and its policies.

In late 1560 , in response to the capture of La Renaudie and his followers for their part in the Amboise conspiracy, Hotman issued a vitriolic attack on the cardinal of Lorraine. ${ }^{23}$ Hotman maintained that the cardinal had usurped the power of the crownarguing that it rightly belonged to the princes of the blood during a king's minority-in order to transfer it to the House of Lorraine. Further, he leveled charges against the cardinal for deliberately corrupting justice by extending the system of venality already omnipresent in parlementary appointments. Hotman's objections were consistent with a line of reasoning that appeared in other Protestant tracts condemning the policies of the Guises. The Huguenot polemicists, maintaining the existence of a Guisard plan to usurp the crown, viewed the Amboise conspiracy as a legitimate act by a loyal nobility who sought to protect the crown from the machinations of a devious foreign contingent within the royal entourage. Critical of the role played by Catherine de Medici, the widow of Henri II, Huguenot pamphlets cited the inviolate nature of the Salic Law of succession in order to frame the actions of La Renaudie and his co-conspirators. The Salic Law, they maintained,

${ }^{23}$ François Hotman, Le Tigre de 1560, ed. Charles Read (Paris, 1875 [reprinted Geneva: Slatkine, 1970]). 
was established in antiquity by the Salien Franks in order to exclude royal descent through the female line. Further the Salic Law, they argued, was designed to prevent a regency connected to the government through women-a reference to the Italian and Catholic queen, Catherine de Medici, as well as to the familial connection of Guise and the cardinal of Lorraine through the Catholic Mary queen of Scots-from exercising control during a king's minority.

The question of the public council was also raised in the wave of Protestant polemic issued in connection with the Amboise conspiracy. Years earlier, Philippe de Commynes cited the actions of the Estates-General that met in Tours in 1484 during the minority of Charles VIII. ${ }^{24}$ Commynes argued that the taxation legislation exacted by the regency government, without the consent of the estates, had resulted in civil war. Using this reference to great effect, the Huguenots pointed to the public council, or estates, as the ancient constitutional body that must grant their consent to the appointment of a regent during a king's minority. Failing to gain that consent, they argued, the regency of Guise and the cardinal was illegitimate; thus the actions of La Renaudie and his followers could be taken as justifiable.

The Catholic response to the Amboise conspiracy was led by Jean du Tillet, the royal historian who served as the clerk of the Parlement of Paris. Du Tillet, while not denying the important role played by the estates in history, argued that custom dictated that French kings could assume their majority at age fourteen. Du Tillet also found objection in the implicit inferences of the Huguenot writers, who he believed to be forwarding a view of the estates as superior to the king, a view that du Tillet rejected as extreme and ridiculous, because it posited the king under the authority of his subjects. Du Tillet, seeking to answer

24 Philippe de Commynes, Mémoires, ed. Samuel Kinser, trans. Isabelle Cazeaux, 2 vols. (Columbia, SC: University of South Carolina Press, 1969). 
Huguenot charges that Francis II's young age negated his capacity to rule, defended his position by citing Tacitus' observations of the customs of the Germanic peoples who came to form the tribes that founded the Frankish kingdom. Tacitus showed that it was customary for the sons of the great men among these tribes to be appointed to high office as a reward for the service of their fathers. ${ }^{25}$ Du Tillet had accepted the Germanic origin of the Franks years earlier, and his reference to the institutions and customs of GermanoFrankish society reflects well the intellectual milieu of a society that was becoming increasingly concerned with finding support and answers for present circumstance in the past.

25 Cornelius Tacitus, Customs of the Germans, in The Complete Works of Tacitus, trans. Alfred J. Church and William J. Brodribb (New York: Modern Library, 1942). 


\section{CHAPTER 2}

\section{HISTORY AND THE REVOLUTION IN PRINT}

The debate centered around the Tumult of Amboise set the stage for the constitutional theories that were to be advanced, by Catholics and Protestants alike, in the coming decades. The issues raised during the early 1560's, the laws of succession and the role of the Estates-General, were to become central to the constitutional debate that framed the religious wars. As the battle of words took shape, the actors in this polemical drama, increasingly sought out the past in the hopes of providing some answers to the political, social, and religious upheaval of the present. As a result, references to the ancient past were found not only within political and religious discourse, but were infused in the popular literature of the period.

The sixteenth-century mind did not conceive of the past in the abstract. It formed a living presence, a model that dictated and shaped one's perception and construction of reality. In France during this period, as with other societies founded on an oral tradition, "the memory of the community involuntarily tends to mask and reabsorb changes. To the relative flexibility of material life corresponds an accentuated immobility of the image of the past."26 The memory of that past, however, is reproduced in the imagination of a community under the influence of social milieu of the present. The extreme fracturing of the social fabric of the communities of sixteenth-century France threatened the collective continuity of those communities' historical memories. As a result, the rapid social change taking place throughout the period necessitated a re-examination of the component parts

26 Ginzburg, The Cheese and the Worms, 77-8. 
that formed the context for this society's perception and understanding of its history and, further, the role that history played in the life of the community.

Many of the popular revolts of the sixteenth century were undertaken not only as a way to gain back rights engendered in lost traditions, but also drew their inspiration from the ethical and religious value systems of the communities in which these uprisings took place. Citing the failure of the nobility to meet its historical tax obligations, Jean du Bourg presented a petition before a meeting of the Estates-General at Blois in 1576. Serving as a demonstration of the influence of humanist scholarship on sixteenth-century political thought-and of Du Bourg's perception of the corruption that had occurred over time-his petition reads:

It will do them [the two privileged estates] no good to say they rule over the Third Estate by long precedent, seeing as how there is no custom, privilege, law or ordinance which is not subject to change and correction when evidence and necessity require, as lawgivers have shown and as Plato says in the fourth book of his laws, a thing should always be taken up and righted by human laws, which he compares to paintings easily erased by the passing of time if they are not touched up. ${ }^{27}$

Du Bourg's petition underscores the sense of longing for the "good old days" that was ingrained in regional tradition. Again, in a Cahier de doléance presented at a meeting of the regional estates in Grenoble in 1579 on behalf of Dauphiné's third estate, Du Bourg expressed his desire to see the return of the immemorial values of liberty and justice that had been lost over time. To the assembly, Du Bourg argued that

The state of the present time is greatly altered and dissimilar from the past. When necessity requires, as it does at present, there is no law, statute, custom, or privilege over which it is not seemly to make new ordinances when evidently and manifestly needful, as legal provisions make wellknown. ${ }^{28}$

27 Emmanuel Le Roy Ladurie, Carnival in Romans, trans. Mary Feeney (New York: George Braziller, 1979), 67.

28 ibid., 70-71. 
When the reconstitution of a mythical past-engendered in traditions concerning the form and nature of civic institutions and rights--was called for in sixteenth century France, that past undertook a fundamental transformation. Hobsbawm argued that "even if the literal attempt to turn the clock back is made, it does not really restore the old days, but merely certain parts of the formal system of the conscious past, which are now functionally different." 29 In his seminal study of the social construction of memory, Maurice Halbwachs noted that

Recollections which have not been thought about for a long time are reproduced without change. But when reflection begins to operate, when instead of letting the past recur, we reconstruct it through an effort of reasoning, what happens is that we distort the past, because we wish to introduce greater coherence. It is then reason or intelligence that chooses among the store of recollections, eliminates some of them, and arranges the others according to an order conforming with our ideas of the present. 30

It was the rearrangement, or realignment, of recollections of the past that led to an historiographic revolution in France in the sixteenth century; a revolution made possible by the advent of the printing press. Printed text accelerated the pace of the classical revival that proved to be the wellspring of the political debates of this period. Elizabeth Eisenstein argued that "until the advent of printing, classical revivals were necessarily limited in scope and transitory in effect; a sustained and permanent recovery of all portions of the antique heritage remained out of reach."31 During the Renaissance, printed text allowed for the systemization and codification of classical and medieval legal traditions. As a result, the past could be observed from a "fixed distance." It was this historical "fixation" that engendered the perception of anachronism that developed in the course of the fifteenth and

${ }^{29}$ Hobsbawm, "The Social Function of the Past: Some Questions," 6.

${ }^{30}$ Maurice Halbwachs, On Collective Memory, trans Lewis A. Coser. (Chicago: University of Chicago Press, 1992), 183.

31 Eisenstein, The Printing Press as an Agent of Change, 217. 
sixteenth centuries. Printed text also amplified and reinforced "old messages": "Since writers are particularly prone to wide-ranging reading, a muliplying 'feed-back' effect results. When it comes to coining familiar quotations, describing familiar episodes, orginating symbols or sterotypes, the ancients... will generally outstrip the moderns." 32 Further, greater publishing in the vernacular occurred in the sixteenth century than at any time before. As a result, "the lay person could now read the texts...for himself; he did not have to rely on a summary made by a scholar."33

However, it has been argued that the French nobility of this period recognized within themselves an inherent limit on their knowledge of political affairs, as represented in written histories; due in part to the great detail that was required of the reader to absorb. The comments of Huguenot leader François de la Noue should be taken as an interesting endorsement of the fact that written representations of the past, in this period, could only be readily understood in terms of general formulations-comments that reinforce the aforementioned premise that it was not the "truth" of the stories that mattered for the average reader, but what they meant to him. La Noue claimed that "Those who write fat histories, having so many facts to present, more numerous than the leaves of a great oak, cannot do so by noting all the particulars that go with them."34

Along this same line, a letter written to Catherine de Medici from René de Mailly also demonstrates the living presence of the past animated in the sixteenth-century mind; a past that could not be known abstractly when objectified, and made somehow distant, in the printed text. Du Mailly wrote to Catherine seeking to protect the privileges his family

32 ibid., 127.

33 Miriam Usher Chrisman, Lay Culture, Learned Culture: Books and Social Change in Strasbourg, 1480-1599 (New Haven: Yale University Press, 1982), 270-271.

34 Jonathan Dewald, Aristocratic Experience and the Origins of Modern Culture: France, 1570-1715 (Berkeley: University of California Press, 1993), 35-36. 
had enjoyed, "since time immemorial," from the reform of customary law that was being undertaken in his region of Picardy. The letter is significant, in that it indicates that, "although written documentation was clearly necessary to the procedures of the official reformation of customary law...[Du Mailly] nonetheless believes that the Queen should rely on his memory of what his family's privileges have been 'from time immemorial' for the purposes of reaffirming the rights in written form." 35

A study of England also articulates the growth of a particular genre of popular literature in this period. Inexpensive books and woodcuts circulated widely in this period. They contained collections of stories, knightly romances and traditional iconography from the Middle Ages that were adapted to reflect on, and provide a sense of comfort to the crises of contemporary circumstances. Drawn from a long-standing oral tradition, these books and images supported the notion of collective standards of community, behavior, and moral conduct, in that they functioned as an aid to memory. They also served as a way to remind the reader of things already known. In this way, increased literacy and the explosion of printed material served to maintain cultural continuity. Though not disregarding the power of print as an agent of change, it has been argued that print could also reinforce a traditional world view through the conservatism that appears again and again in the medieval chivalric stories and "pre-Reformation visions of the afterlife" that appear so frequently in these books. ${ }^{36}$

35 Kristen B. Neuschel, Word of Honor: Interpreting Noble Culture in SixteenthCentury France (Ithaca: Cornell University Press, 1989), 112-114.

36 Tessa Watt, Cheap Print and Popular Piety, 1550-1640 (Cambridge: Cambridge University Press, 1991). 


\section{CHAPTER 3}

\section{HISTORY AND THE START OF THE CIVIL WARS}

The character of a nation's laws, and the ideas that underlie those laws, affects that nation's relationship with its past. When French legal scholars applied humanist philological techniques to the study of Justinian's corpus juris, they demonstrated that Roman law could not be regarded any longer as a universal body of law. Particularly after the publication of a standardized and amended version of the Florentine Codex of Justinian's Digest by Jacques Cujas in 1553, "ancient compilations such as the Corpus Juris seemed less relevant to current practice." 37 The notion of relativism that was bom in the Renaissance not only brought into question normative standards and the trans-cultural applicability of bodies of law, but also of political, religious, and social systems. Up until this period, most Frenchmen had assumed a shared Trojan heritage with classical Rome. The proponents of the mos gallicus method of legal scholarship succeeded in creating a heightened sense of cultural self-awareness among their contemporaries. Drawing on the influence of humanist jurisprudence, historians and antiquaries began to retrace the history of France back to the its non-Roman origins in the ancient Gauls and Franks.

In the course of sixteenth century, this recreation of the national past took on a patriotic dimension heretofore absent from traditional, chronicle-styled medieval histories. In the search for the sources of contemporary institutions and practices, the creation of a new, uniquely Gallican mythology, stood defiantly as a rival to the cultural heterodoxy of Rome. When contrasted with the corrupt and "tyrannical" legal and social heritage of Rome, the mythic constitution of the ancient Gauls and Franks was raised as a symbol of ancient liberty that had been lost, or perverted, in the course of history. Clifford Geertz

37 Eisenstein, The Printing Press as an Agent of Change, 103-4. 
argued that it is "precisely at the point at which a political system begins to free itself from the immediate governance of received tradition, from the direct guidance of religious or philosophical canons on the one hand and from the unreflective precepts of conventional moralism on the other, that formal ideologies tend to first emerge and take hold."38

The historical fiction that developed out of the effort to demonstrate the ancientness of the French constitution became, in the course of the sixteenth century, a functioning political ideology. Around this ideology, new modes to discourse developed which reflected the mentalite of a culture struggling to understand the reality of the present through a recreation of the mythic past. The vocabularies of this discourse, created "in order to express precise French constitutional precepts,"39 came to form a new language of French public law and constitutional ideology. In looking at the growth of this national mythology cum ideology, Claude-Gilbert Dubois found that in the sixteenth century

Le présent fonde le passé. Le myth du Gaulois permet une cristillisation, autour d'un archétype riche en symboles, d'aspirations diverses, sans rapport immédiat avec le contenu historique, mais en rapport analogique avec l'actualité...La résistance des Gaulois à l'envahisseur symbolise la volonté de se libérer de Rome (et derrière le nom de Rome, il faut lire, au $\mathrm{XVI}$ e siècle, la ville des Papes et l'emprise culturelle italienne). ${ }^{40}$

The articulation of the unique character of French institutions, customs, and lawsas distinct from those of Rome-also succeeded in drastically altering the perception of historical time. However, though the world view of sixteenth-century French society was expanded under the weight of humanist scholarship, it remained conceptually sterile. Our "modern" society understands that the process of historical development produces a variety

38 Clifford Geertz, Interpretation of Cultures (New York: Basic Books, 1973), 219.

39 Sarah Hanley, The Lit de Justice of the Kings of France: Constitutional Ideology in Legend, Ritual, and Discourse (Princeton: Princeton University Press, 1983), 7-11.

40 Claude-Gilbert Dubois, Celtes et Gaulois au XVI ${ }^{e}$ siecle, le developpement littéraire d' un myth nationaliste (Paris, Jurin, 1972), 45. 
and diversity of models of human existence. In this period, however, this diversity was not readily understood. In the chaos necessitated by a world view drastically altered through the lens of relativism, sixteenth-century Frenchmen struggled to construct an intellectual framework which would serve to impose some sense of order on their conception of historical reality.

French humanist legal scholars had revealed the complexity of historical reality through an examination of the classic texts of jurisprudence. They became increasingly critical of the medieval codifiers of these ancient laws, in part because it was determined that a body of law must be appropriate to the state in which it was designed to govern. In the light of the inconsistencies exposed by sixteenth-century scholars, the medieval glosses of Justinian's corpus juris were seen as anachronistic. These inconsistencies in the written sources made questionable not only the appropriateness of Justinian's code for contemporary France, but even for Justinian's own time. Further, by the sixteenth-century knowledge of the New World, the Indies, and the Near East forced Europeans to the realization "that the peoples in these areas lived lives different from their own and had their own religious beliefs;" a realization which necessitated an awareness that "all men lived in a larger cosmos." 41

In the light of that realization, the connection between the Reformation and the historical "revolution" that took place in Renaissance France is inescapable: "Just as evangelical reformers sought to be 'free' from papal materialism in a purified church, [French humanist scholars, propagandists, historians, and politicians] sought to be free of Italianate oppression in a purified constitution." 42 A heightened sense of cultural self-

41 Chrisman, Lay Culture, Learned Culture, 274.

42 Donald R. Kelley, The Beginning of Ideology: Consciousness and Society in the French Renaissance (Cambridge: Cambridge University Press, 1981), 293-294. 
awareness, the result of an intense effort to recreate and redefine the origins of contemporary institutions, generated the decidedly "modern" perception that France should be understood as a "concept which can only be defined through its history." 43

The advent of the printing press was inexorably linked with the rise in humanist learning and the historiographic revolution that took place in sixteenth-century France. It was because Roman law had been written, could now be printed and copied, that its contextual relevance for contemporary France was questioned. Further, the popularity of Commynes, Froissart and the other "greats" of French historiography testifies to the shifting of opinions regarding the purpose of history. 44 These writers represented a marked change from the medieval chroniclers, in that they not only narrated, but provided moral commentary to the events they described. The moral lesson learned from history was especially appealing to the French middle class, and marks a distinct point of difference between the French and Italian Renaissance.

Between 1550 and 1610 some 657 books of history were published in Europe; more than half of them between 1560 and 1588.45 Under the influence of humanist legal scholarship, the effort to distinguish material causation in historical change became increasingly identified with origins. It was believed that, in order to find the "substance" of history, one must seek to explore its origins and "progress" over time. History represented a storehouse of knowledge that, through a critical examination of the sources which contained that knowledge, could be classified and organized in order to articulate causality.

43 George Huppert, The Idea of Perfect History: Historical Erudition and Historical Philosophy in Renaissance France (Urbana, IL: University of Illinois Press, 1970), 64.

44 For more on the popularity of these writers, see: A.H. Schutz, Vernacular Books in Parisian Private Libraries of the Sixteenth Century According to the Notorial Inventories (Chapel Hill: University of North Carolina Press, 1955).

45 Corrado Vivanti, "Paulus Aemilius Gallis condidit historias?" Annales: Economies, sociétés, civilisations, 19 (1964): 1117-1124. 
As has been stated previously, history functioned as a living mythology. The activation of that mythology, in the sixteenth century, can be more readily perceived when one recognizes that

\begin{abstract}
A sense of the living presence of the source is manifest in the Renaissance treatment of words, things, individuals, and institutions. The vitality of the source-what one is tempted to call extratextuality-shapes the period's understanding of history, contributes to the strength and complexity of the presence of earlier events in Renaissance texts, and accounts for the rhetorical energy invested in certain recurrent themes: Renaissance interest in resurrection, progress, and creativity brings a specific urgency and flavor to the consideration of the continued expression of the sources. ${ }^{46}$
\end{abstract}

The meeting held between Catholic and Calvinist theologians at Poissy in September of 1561 , was a seen as a last-ditch effort to reconcile religious differences that had brought France to the brink of civil war. However, the intractability of the leaders of both sides-Théodore de Bèze representing the Protestant delegation and the Jesuit general, Diego Lianez, representing the Catholic-doomed the colloquy to failure. With the two sides unable to reach a confessional compromise, and faced with the choice of enforcing heresy laws or of legal toleration of Huguenot dissent, as a temporary expedient the new Chancellor, Michel de l'Hôpital, decided on the latter. L'Hôpital issued an edict in January of 1562 that permitted Huguenot worship outside town walls. Though the parlements reluctantly registered the edict, the massacre of a Huguenot congregation in Vassy by François de Guise signaled the start of what would become a full-fledged civil war in the summer of that year.

From the summer of 1562 to March of the following year, Protestant and Catholic forces were engaged in a fiercely contested battle for control in the provinces. In the course of 1562-3 the death of Antoine de Bourbon during the siege of Rouen, the capture of Louis de Condé at Druex, and the assassination of François de Guise by Poltrot de Méré, left

46 Marian Rothstein, "Etymology, Genealogy, and the Immutability of Origins," Renaissance Quarterly, 43 (1990): 332. 
each side in the conflict without their major military leaders. Seizing upon this opportunity, Catherine de Medici-who had by now assumed full control of the regency governmentdictated the peace of Amboise in the spring of 1563. By the terms of the peace, the Protestant nobility were extended the right to preach and worship on their estates and Protestant worship was permitted in the towns held by Huguenot garrisons. However, the edict was strongly rejected by the Parlement of Paris and the Catholic-dominated parlements of Toulouse, Dijon, and Rouen. Despite the intensive efforts of the queen mother, many of the provincial parlements refused to recognize the Protestants' right to worship. ${ }^{47}$

Between the signing of the Peace of Amboise in 1563 and the resumption of violence with the start of the second civil war in 1567 , the in-fighting among the nobility presented as great an obstacle to the peace as did differences of religion. During his inaugural address to the Parlement of Paris in 1560, the new chancellor Michel de l'Hôpital, pleading for "une foi, une loi, un roi," urged an end to religious difference. Yet, in a speech delivered before a meeting of the representatives of the parlements held in SaintGermain in January 1562, though he still regarded uniformity of faith as desirable, L'Hôpital argued that its enforcement would greatly endanger France. ${ }^{48}$ Bearing this in mind, L'Hôpital took it upon himself to exert his influence to try to mitigate the factional division among the noblesse, and to seek a resolution to the religious question.

47 For a more comprehensive discussion of the religious wars in the provinces, see: Philip Benedict, Rouen during the Wars of Religion (Cambridge: Cambridge University Press, 1981); Joan Davies, "Persecution and Protestantism: Toulouse 1562-1575," Historical Journal, 22 (1979): 31-51; A.N. Galpern, The Religions of the People in Sixteenth-Century Champagne (Cambridge, MA: Harvard University Press, 1976); Gustave Lambert, Histoire des guerres de religion en Provence, 1530-1598, 2 vols. (Nyon, 1972).

48 Quentin Skinner, The Foundations of Modern Political Thought, 2 vols. (Cambridge: Cambridge University Press, 1978), II: 250-251. 
At the heart of L'Hôpital's effort was his desire for a far-reaching program of judicial and administrative reform. In 1518, Claude de Seyssel had argued that the French government was dependent on "tradition, reason, and necessity."49 L'Hôpital, too, respected and believed in the authority of tradition. He decried the fact that there had been no meeting of the Estates-General since that called during the reign of Charles VIII in 1484. He also believed that throughout history the estates had played an important role as a source of advice to the king, and in being able to communicate the policies of the crown to the country at large.

However, the precariousness of the peace accord reached at Amboise in 1563 led L'Hôpital to the conclusion that royal authority was the only way in which the king, as the sovereign administrator of justice, could maintain Gallican unity. Like many of his contemporaries, L'Hôpital struggled with a reverence for tradition and the realization that contemporary problems required novel remedies that could not practically be accomplished by simply returning to past practice. As a result, L'Hôpital "envisaged a policy in which royal power, limited only by divine and fundamental law, would effectively promote the interests of the subjects against opposition from the magistracy and other privileged groups." 50 L'Hôpital's distaste for the system of venality, which he believed had corrupted French civil government, led him to issue the Edict of Orléans. The Orléans edict represented an aggressive program of reform which called for the dismantling of all government offices that had been created since the reign of Louis XII and an end to pluralism within the offices of justice and finance.

49 Claude de Seyssel, The Monarchy of France, trans. J.H. Hexter, ed. Donald Kelley (New Haven: Yale University Press, 1981).

50 Seong-Hak Kim, "The Chancellor's Crusade: Michel de l'Hôpital and the Parlement of Paris," French History, 7 (1993): 18-25. 
Advancing his position in a speech given in Moulins in February of 1566 , L'Hôpital attacked the proliferation of laws and the confusing maze of conflicting jurisdictions within the judicial system. Invoking the principles set forth by Seyssel nearly forty years earlier, L'Hôpital spoke "nostalgically of an earlier time when the laws were few and simple, founded on 'good customs and natural judgment'."51 He believed that the competition for offices and the jurisdictional disputes between magistrates-who, through a nepotistic system of venality, had gained family monopolies on judgeships-hampered the swift dispensation of justice. As a result, he decreed that superfluous présidiaux, courts that had been established in 1552 between the provincial parlements and the bailliage courts, were to be eliminated. L'Hôpital then established a limitation of appellate jurisdiction within the courts.

L'Hôpital's actions against the parlements bear witness to his concern for the independent jurisdiction of the magistracy. He believed that the parlements not only had been instituted by the king, but "held their authority exclusively from him."52 Therefore, L'Hôpital argued, the king possessed the right to modify their jurisdiction. By the Edict of Moulins, L'Hôpital relieved the municipal courts of the parlements of their jurisdiction in civil cases, and he instituted a process whereby tours of inspection would be made by a royal maitre des requêtes to insure that the policies of the crown, with regard to the parlements, were complied with.

L'Hôpital's ideas regarding the reform of justice, and his willingness to allow for religious toleration, appealed to many within the Huguenot party. However, the chancellor's program of legislation was viewed as heavily paternalistic. Though L'Hôpital espoused reverence for ancient custom and constitutional practices, his emphasis on the

51 Salmon, Society in Crisis, 156.

52 Kim, "The Chancellor's Crusade," 13. 
legislative authority of the king was taken by many as sign that L'Hôpital viewed the estates as merely a petitionary and advisory body. As a result, many Huguenot jurists believed that the latitude within which L'Hôpital argued the king could make or unmake law belied the chancellor's unwillingness to recognize the immutability of ancient edictswhich many in the Party viewed as sacrosanct.

Not long after L'Hôpital's declaration at Moulins, François Hotman articulated an early constitutional position of the Huguenots in his treatise, Antitribonian-a reference to the codification of Roman law assigned to Tribonian by Justinian. In order to effect a thorough-going reform of justice, Hotman proposed that a judicial assembly be called to codify public and private law. The Antitribonian echoed L'Hôpital's beliefs concerning the reform of the administration of justice and private law. However, Hotman parted with the chancellor on constitutional issues. Whereas L'Hôpital had provided the king with broad discretionary powers, in regard to the coutumiers, Hotman argued that the proposed assembly should be granted less freedom to reshape public law and the "constitution" because they were "the product of history." 53

Hotman's earlier works had demonstrated the anachronistic character of the medieval codification of Roman law and questioned its relevance to contemporary France. However, in the Antitribonian, Hotman argued that the adoption of a single body of French customary law would greatly simplify the administration of justice. As a result, the Antitribonian contains an interesting paradox. One the one hand, the work presented itself as an attack on Roman law. While on the other hand, Hotman concluded that it should play a prominent role in the reform of French law. How was this striking contradiction resolved?

53 Hotman, Francogallia, 33. 
Hotman was growing impatient with the slow progress of a commission headed by Christofle de Thou, which was presently involved in the rédaction and comparison of the coutumiers. His frustration with de Thou's efforts led him to argue that, in matters of private law, the laws of a commonwealth should be constructed so as to reflect the political structure of that commonwealth. Hotman did not regard customary law as being any more important than any other system of law. On the contrary, he argued that any body of law must be studied critically in order to determine context and applicability. Hotman believed that because "custom in France existed side by side with Roman law it was possible to envisage the two growing up together in a single historical process." 54 Reflecting this belief, Hotman proposed a reform of the system of French legal education. He saw it as impractical for a prospective magistrate to learn about the function of the judiciary in ancient Rome or Constantinople. Instead, Hotman argued, they should be required to study the history of the French constitution and the various public offices. This proposal reflected Hotman's belief that "public functions should be explained in terms of history."\$5

On the issue of private law, Hotman proposed that a reformed system of French law should be constructed from normative standards of equity and uniformity drawn from Roman law. He argued that "although Roman law was no longer the standard of jurisprudence it still embodied legal principles...from which a new body of universal law could be distilled."56 Reflecting a desire for expediency, Hotman was willing to dispense with the futile task of standardizing and organizing the morass of local customs found within the realm of French private law. On this count, Hotman was in agreement with

54 J.G.A. Pocock, The Ancient Constitution and the Feudal Law: A Study of English Historical Thought in the Seventeenth Century, 2nd edition (Cambridge: Cambridge University Press, 1987), 28-29.

55 Hotman, Francogallia, 35.

56 Schiffman, "Humanism and the Problem of Relativism," 71-72. 
L'Hôpital's reformist policies. In the Antitribonian, Hotman allowed for more autocratic measures to be taken by the government, in order to provide for a more equitable and efficient dispensation of justice.

The work of L'Hôpital and Hotman reflects an intellectual struggle between idealized traditionalism and practical reform that characterized this period. On the one hand, Hotman and other Huguenot legists revered tradition and custom and sought to capture the essence of the ancient French "constitution" and age-old standards of equity to address the reform of justice. On the other hand L'Hôpital, though he too believed in the authority of tradition, was willing to suggest innovative approaches as remedies for the problems of the present. 


\section{CHAPTER 4}

\section{DEVELOPMENT OF AN IDEOLOGY}

Claude-Gilbert Dubois argued that in the historical debates of the sixteenth century "la réflexion méthodologique est orientée contre le dogmatisme: c'est vrai dans tous les domaines, qu'il s'agisse des attaques à l'égard de la méthode scolastique, de la remise en cause, dans le domaine juridique, de l'autorité dont jouissait le droit romain, de l'analyse critique des croyances surajoutées à la religion au cours des siècles. C'est l'ensemble d'un système de valeurs intellectuelles qui est remis en question." 57 This was certainly the case after the start of the second civil war in the fall of 1567.

Though there were brief interludes of tenuous peace, the changes in royal policy that occurred in the course of the second and third civil wars forced a re-evaluation of Huguenot political philosophy. Between 1567 and 1572, Huguenot pamphleteers stepped up their criticism of royal policy. The massacre of Saint Bartholomew, however, was the lightening bolt for the Huguenot party that precipitated a radical shift in the tenor of their political propaganda. The slaughter of as many as 13,000 Huguenots in the weeks following the assassination of the party's leadership in Paris in August of 1572, proved to many that doctrines of constitutionalism and limited monarchy were no longer adequate.

A flood of Protestant propaganda was issued in support of Huguenot military campaigns during the fall of 1567 . The financial crisis that plagued the country throughout the decade had succeeded in rendering, as ineffective, L'Hôpital's effort to check the system of venality in the government. Further, the failure of the monarchy to follow through on the promises of reform issued by the Orléans estates in 1560, and the

57 Claude-Gilbert Dubois, La Conception de l'Histoire en France au XVIe siècle (1560-1610) (Paris: Nizet, 1977), 69. 
undermining of the edicts of toleration by Guisard and other "foreigners" in the government, led the leadership of the Huguenot party to call their co-religionists to arms.

Huguenot constitutional thought, at this time, was comprised of an image of an idealized vision of a medieval monarchy working in partnership with an idealized vision of the estates. The propaganda of $1567-8$ recalled a similar uprising by the noblesse a century before, in which the lesser nobility took up arms against Louis XI for his failure to seek support for his taxation policies from the Estates-General. The present conflict, they argued, was the result of the monarchy which had broken its ancient constitutional relationship with the nobility and the provincial estates.

The language framing the constitutional debate changed noticeably after the spring of 1567. In March of that year Huguenot uprisings took place throughout France and, by September, Huguenot military forces had succeeded in capturing Mâcon, Nîmes, Orléans, Valence, Montpellier, Valence, and Auxerre..$^{58}$ The constitutional arguments employed by Huguenot pamphleteers in this period echoed the strains of Germanist historicism found earlier in Hotman's Antitribonian. In his investigation of the origins of French institutions, Hotman had traced the development of contemporary French law from the Frankish occupation of Gaul. Similarly, the pamphlets of 1567-9 romanticized the constitutional role played by the ancient Frankish estates. Since the first Frankish kings had succeeded in gaining Gaul from the Romans, it was argued, the estates served as an equal partner in the maintenance of civil liberty. Beyond providing counsel to the Frankish kings, it was argued the ancient estates maintained the right to bring remonstrance against the king if he did not fulfill his "constitutional" obligations to his subjects. Therefore, the subversion of the Edict of Orléans was viewed as a tyrannical act by a monarchy that had clearly exceeded its constitutional authority.

58 Salmon, Society in Crisis, 169. 
Further, these tracts also articulate the development of Huguenot contractual theory in this period, in that it was inferred that monarchical legitimacy is dependent on the election of kings by the consent of the people through the assembly of the estates. Linking the election of kings with the duty to provide kingly counsel through regular meetings of the estates, the Huguenot supporters of the present revolt claimed that the "ancient constitution had been subverted, and ought to be restored." 59

However, from the perspective of the government, the attempted capture of the royal court at Meaux, by a large contingent of Huguenot militiamen, necessitated a change in royal policy. This Huguenot cabal, and the involvement of Huguenot pirates from New Rochelle and Normandy in William of Orange's battles against the Duke of Alba in the Netherlands, led Catherine de Medici-who remembered all too well the attempted coup of Amboise - to attempt to protect her base of power. Catherine realized that if the Guises succeeded in their plan to impose religious uniformity, it would necessitate overcoming their rivals among the Huguenot nobility. This accomplished, they would effectively become the dominant political force in France. As a result, the queen mother recognized that her best hope of retaining power was to concede the Huguenots a measure of religious liberty. Given the intractability of Condé and the Guises, this policy was doomed to failure.

The start of the second civil war provoked a fiery response from the supporters of the monarchy. One of the most articulate and vocal critics of the Huguenot rebellion was Jean du Tillet, who served from 1530 to 1570 as the royal prothonotary and secretary, and as the greffier civil of the Parlement of Paris. ${ }^{60}$ Under the patronage of the humanist king,

\section{Hotman, Francogallia, 40.}

60 For more on the career and writings of Du Tillet, see: Elizabeth A.R. Brown, ed., Jean du Tillet and the French Wars of Religion: Five Tracts, 1562-1569 (Binghamton, NY: Center for Medieval and Early Renaissance Studies, 1994); Sarah Hanley, The Lit de Justice of the Kings of France: Constitutional Ideology in Legend, Ritual, and Discourse 
Francis I, Du Tillet spent many years involved in archival research. Du Tillet's stated purpose for his Recueil des Roys de France, a collection of three works, was to provide the king with a critically analyzed inventory of the documents contained in the Paris archives. Included in the Recueil was a history of the crown, a survey of the development of French law, royal ordinances, and relations between England and France. Du Tillet saw his tedious mission in the archives as an effort to reclaim a "mirror of the French past" from "fabricated fables committed to short chronicles"; fables which, for Du Tillet, resulted in fiction, not fact. ${ }^{61}$

Until his death in 1570, Du Tillet proved himself an uncompromising advocate of royal authority, and the series of pamphlets he produced in the course of the first three civil wars reflect his distrust of and distaste for the Huguenot rebels. During the succession crisis of 1560, Du Tillet utilized his vast knowledge of French legal history to defend the rightful majority of Francis II, as dictated by ancient Franco-Gallic tradition. Further, he vehemently rejected Huguenot demands for a meeting of the Estates-General, on the grounds that, historically, the estates functioned merely as a consultative body and not as the guardians of royal authority.

After the outbreak of the second civil war, Du Tillet penned two of his most famous works. Both pamphlets are reflective of Du Tillet's impressive learning and command of the sources of French history. In the first, entitled Memoire enuoye au Roy pour le Iugement des Rebelles, Du Tillet charged the Huguenots guilty of the crime of lese maieste - treason against God (heresy) and the king. Employing a variety of historical examples detailing how traitors were dealt with in the past, Du Tillet's goal was to convince

(Princeton: Princeton University Press, 1983); Donald Kelley, "Jean du Tillet, Archivist and Antiquary," Journal of Modern History, 38 (1966): 337-354.

61 Hanley, The Lits de Justice, 105-106. 
the king that swift and decisive action should be taken against the heretical rebels. Du Tillet argued that a policy of leniency towards the Huguenots was dangerous, because

Heresy is the inseparable companion of sedition. This is shown by the miseries that liberty of conscience and toleration of two religions have inflicted on the kingdom in so few years, miseries that still continue. False religion will inevitably arise again if the king does not firmly refuse his grace to all heretics save those who return to the Church in the manner that the Church ordains. ${ }^{62}$

In linking the crime of lese maieste against divine, as well as human law, the struggle against the Huguenots further provoked a crusading zeal among the supporters of the king - a zeal that has been shown to have been very important for those engaged in the struggle against the Huguenots, in that the Protestants were viewed as enemies of both God and the state. ${ }^{63}$

In the Escript touchant la paix des secondz troubles au Roy, written prior to the signing of the Peace of Longjumeau in the winter of 1568 , Du Tillet called for the total submission of the rebellious "children of Satan." Du Tillet, entreating the king that the Huguenots, merely "pretending dedication to the public weal," had shown their "design to vanquish and dictate to you, not humbly petition, since they continue to fight because you have not agreed to their demands." Further, Du Tillet argued, the Huguenots, in asking for guarantees, acted

as if the edict of pacification subordinated you to them, which would be submission repugnant to the grandeur and rights of your crown and would pervert the order instituted by God. This proposition is proved by numerous examples from the history of France...[which] demonstrate that the king is not obligated to observe safeguards or promises given to rebels. The king's word is law, and subjects can only humbly petition as divine ordonnances dictate. ${ }^{64}$

62 Brown, Jean du Tillet, 119.

63 Denis Crouzet, Les guerriers de Dieu. La violence au temps des troubles de religion, vers 1525-vers 1610, 2 vols. (Seyssel: Champ Vallon, 1990), I: 377-411.

64 Brown, Jean du Tillet, 137. 
Under pressure from ultra-Catholics in the court and the Parlement of Paris, who believed that Huguenot involvement in the struggle between William of Orange and the Duke of Alba would provoke retribution from Philip II, the queen mother revoked the Edict of Longjumeau which had been signed the previous year. As a result, the Huguenots again mobilized their forces; a move that signaled the start of the third civil war. The Huguenot leadership blamed the resumption of open hostilities on the devious machinations of the cardinal of Lorraine-who was seen as secretly supporting Spanish interests in the Netherlands, as well as Catholic plots in England in favor of Mary queen of Scots-and other "foreigners" in the government.

The meeting between Catherine de Medici and the Duke of Alba during a royal inspection tour, and the subsequent invasion of the Netherlands by Spanish forces, enhanced the feelings of persecution already held by the Huguenot minority. The meeting signified, to the Protestants, that "The King of Spain, having entered into a league with the Emperor, the Pope and other princes in order to exterminate those of the religion, summoned the King [of France] to do the same and to sign the articles of the Council of Trent, which the Cardinal of Lorraine has been so solicitous about."65

The third war lasted from September 1568 to August of 1570. In August of 1570, a peace accord was reached between the combatants. The Edict of Saint-Germain restored most of the privileges afforded the Huguenots under the terms of previous pacification edicts, and allowed Protestant worship in all towns which had practiced the Reformed faith prior to the start of the war. Though both sides remained skeptical of the peace, the plans for an upcoming royal marriage elevated spirits and took some of the focus off the previous years' violence. A marriage between Marguerite de Valois, the youngest daughter of Catherine de Medici, and the son of the Huguenot noblewoman Jeanne d'Albret, Henri de

65 Kelley, The Beginning of Ideology, 283. 
Navarre, was seen by the queen mother as a way to heal past enmities and promote greater toleration.

While the plans for the Bourbon marriage were being finalized, a rift opened between the queen mother and her son, Charles IX, over the engagement of Huguenot forces in the Netherlands. Against the wishes of his mother, the king had secretly allowed Huguenot forces, under the leadership of Admiral Gaspard de Coligny, to assemble in the French town of Soisson to prepare an incursion into the Netherlands. De Medici summoned the council to discuss the matter. Not wishing to further antagonize the Spanish, the royal council voted for peace. Despite the vote of the council, Coligny moved forward with his plans to invade the Netherlands. Seeking to avoid a war with Spain, members of the Catholic faction began to plot Coligny's death.

In August, the Huguenot nobility assembled in Paris to celebrate the marriage of Henri de Navarre and Marguerite de Valois. Four days after the couple exchanged their vows, Admiral Coligny was struck by an assassin's bullet. Responsibility for the plan has been hotly contested. Indeed, a whole body of literature has grown out of this question. Though the assassin failed in his plan to kill the admiral, the Huguenot nobility demanded justice. The king, promising satisfaction, met with his advisors in the hopes of finding the culprit in the case. The proceeding took a disastrous turn for the Protestants when Charles IX was persuaded that the Huguenots were not merely seeking religious toleration, but indeed were plotting the overthrow of the government. As a result, the king sanctioned the executions of Admiral Coligny and rest of the assembled Huguenot leadership. However, the killing was not limited to the party leaders. The involvement of the Paris militia in the action unleashed the fanaticism of the decidedly anti-Protestant Parisian population. ${ }^{66}$ In

66 For further reading on the causes and events of the massacre, see: Barbara Diefendorf, Beneath the Cross: Catholics and Huguenots in Sixteenth Century Paris (Oxford: Oxford University Press, 1991), and "Prologue to a Massacre: Popular Unrest in Paris, 1570-1572," American Historical Review, 90 (1985): 1067-1091; Donald 
the days that followed, Protestant casualties may have reached as high as 13,000 as the wave of violence rolled out from Paris to the provinces.

During the early stages of the civil wars the basic strategy of the Huguenots was to avoid, in as much as that was possible, direct confrontation with the government of Catherine de Medici. Pinning their hopes on the possibility of winning a measure of official toleration, they framed their criticism around a fiction that they were merely opposing the government's enemies. In the course of the civil wars, Huguenot doctrines of constitutionalism and limited monarchy began to be laced with more abstract theories regarding the nature of the political obligation and the responsibility of the ruler to his subjects. Where humanist philological enterprises had succeeded in demonstrating the uniqueness of French customs and customary rights, French "historians" had shown that throughout history the monarchy had been held in check by a body of Franco-Gallic law. Looking further into the origins of these laws, the political theorists of the 1550's and 1560 's expressed an increasing awareness of the existence of an ancient French constitution, and the origins and authority of the Estates-General. There developed the view of the estates as an essential feature of the ancient constitution. History had shown, it was argued, that the estates-as a body representative of the public will, whose legal responsibility it was to uphold the laws of the kingdom through the dispensation of justice-functioned as the primary counsel to the king, ensuring that the decrees and edicts of the king were in line with the fundamental laws of the kingdom. As a result, it was concluded that no royal edicts or decrees were binding, save those ratified by the estates.

Drawing on medieval conciliarist arguments linking church and crown, political rhetoric during this period also increasingly expressed the primacy of the contractual Kelley, "Martyrs, Myths, and the Massacre: The Background of St. Bartholomew," American Historical Review, 77 (1972): 1323-1342; Robert Kingdon, Myths about the St. Bartholomew's Day Massacres, 1572-1576, (Cambridge, MA: Harvard University Press, 1988). 
relationship that existed between sovereign and subject. It was argued that the contract was instituted by God, through the person of the king, and, if broken, it might be enforced by society - or rather the corporate body of the people as vested in the estates. ${ }^{67}$ Citing an impressive array of historical precedents, it was shown that this contractual relationship had formed an integral part of the system of French government since before the consolidation of the Franco-Gallic empire under Charlemagne. The antiquity of this constitutional relationship was paramount, because the key to the constitutional theories developed by the Huguenots in this period were hinged on the belief that if they could demonstrate that laws were as old as, or older than, the kings, they might go on to assert a contractual or elective basis for kingship; but if the laws had come into being at a time when there was already a king, then nothing but the king's authority could have sanctioned them or made them law, and the king might assert a sovereign right to revoke what his predecessors had granted. ${ }^{68}$

As a result, the Huguenots "used talk about covenants as one of a number of ways to support their contention that a relationship of mutual, but also conditional, obligation existed between rulers and ruled...[Therefore] the division of France into warring parties made a treaty (pacte) with mutual guarantees the obvious remedy."69 However, given his unwillingness to recognize the declarations of the Orléans estates in 1560, and his involvement in the events of Saint Bartholomew, many Huguenot polemicists increasingly identified the king as a tyrant. They argued that, since the monarchy was established on the basis of a contractual arrangement (an arrangement which had been voided in the course of the present conflict), overthrow of the king could be justified. This line of argumentation

67 For a comprehensive treatment of medieval conciliarist theory, see: Brian Tierney, Foundation of Conciliar Theory (Cambridge: Cambridge University Press, 1955).

68 Pocock, The Ancient Constitution and the Feudal Law, 17.

69 Harro Höpfl and Martyn P. Thompson, "The History of Contract as a Motif in Political Thought," American Historical Review, 84 (1979): 933. 
formed the basis of the Huguenot theory of resistance right, as it developed in the course of the latter civil wars. In this regard, resistance no longer became a matter of personal choice, but rather was viewed as a duty to be performed for the good of the corporate body of citizens. 


\section{CHAPTER 5}

\section{HISTORY AND NATIONALISM}

In the light of the developments in historical scholarship that occurred in the 1550's and 1560's, the rhetoric assault on the monarchy which succeeded the events of August 1572 must be viewed within the conceptual framework that defined an understanding of history and kingship in this period. In order to provide meaning to the constitutional debates that raged in this period, the section that follows will seek to articulate the extent to which notions of French kingship in the sixteenth century were inextricably linked to the understanding, or misunderstanding, of history.

Through examples drawn from a variety of sources, the focus of this paper will now be turned to a challenge of what have become widely-held assumptions regarding French historiography in the sixteenth century-assumptions influenced in no small measure by the work of J.G.A. Pocock, Donald Kelley, and George Huppert. ${ }^{70}$ At the heart of this discussion will be an effort to make a distinction between modern historical consciousness and modern historical scholarship, as it developed in the course of the sixteenth century in France. Historical scholarship led to a greater understanding of historical and cultural relativism—as evidenced by the understanding of anachronism engendered in the work of French humanist scholars-and served as a catalyst to a deeper appreciation of the individuality of French institutions and customs as historic entities.

70 George Huppert, The Idea of Perfect History: Historical Erudition and Historical Philosophy in Renaissance France (Urbana, IL: University of Illinois Press, 1970); Donald Kelley, Foundations of Modern Historical Scholarship: Language, Law, and History in the French Renaissance (New York: Columbia University Press, 1970) and Donald Kelley, The Beginning of Ideology: Consciousness and Society in the French Reformation (Cambridge: Cambridge University Press, 1981); J.G.A. Pocock, The Ancient Constitution and the Feudal Law: A Study of English Historical Thought in the Seventeenth Century, 2nd ed. (Cambridge: Cambridge University Press, 1987). 
However, though these customs and institutions came to be seen as unique by virtue of their origins and history, the sixteenth-century mind was unable to adequately perceive, in the modern sense, of their development over time. The inability to perceive this historical development precluded a capacity to view the past "objectively"- thereby undermining the notion of historicism that defines "modern" historical consciousness. It has been argued that "whereas in our present society we occupy a definite position and are subject to the constraints that go with it, memory gives us the illusion of living in the midst of groups which do not imprison us, which impose themselves on us only so far and so long as we accept them. [Therefore] If certain memories are inconvenient or burden us, we can always oppose to them the sense of reality inseparable from our present life."71

Such was the case for sixteenth century France. Though the primacy of normative standards derived from antiquity - taken here to mean Roman — was challenged under the weight of French humanist philological exegesis, constitutional theorists (and one could say French society at large) transposed normative standards found in ancient French institutions and customs on their perception of present circumstances. In this process, these institutions and customs themselves became a norm to be emulated. In the course of the sixteenth century, the return to this norm became the intellectual process by which the present was contrasted with the past. Sixteenth-century Frenchmen "could not even conceive of an [historical] entity as developing in relationship to its circumstances, for such a notion would have obliterated the very "thisness" which defined that entity. Instead, they conceived of it as unfolding from its germ or essence, a conception which enabled them to perceive its "thisness" despite its historical mutations."72

71 Halbwachs, On Collective Memory, 50.

72 Zachary S. Schiffman, "Renaissance Historicism Reconsidered," History and Theory, 24 (1985): 182. 
Thus an historical fiction, manifest in the effort to reclaim and reconstitute the immemorial institutions of the French state, became the cornerstone of a functioning political ideology. Similarly, this historical fiction influenced the way in which French society, generally, understood its history. At the level of popular culture, the belief that legends of the past "could express an exemplary truth similar to that for which history was traditionally held responsible continued throughout [this period] to blur the distinction between history and imaginative expression." 73 In this regard, Renaissance poetry, too, "not only passed on the values of the ancients to the early modern age, but endowed contemporary verse." 74

A study of the royal letters of pardon and remission further demonstrates the blurring of the fine line between fact and fiction that occurred in the sixteenth-century mind. Within these tales, "good moral reasoning had been adduced for vraisemblance: the more probable a story, the more instructive it was."75 The construction of these pardon tales relates, in no small way, to the same lack of clarity manifest in the constitutional debates of the period. [Thus, it has been argued, one should find no real surprise in the pardon tales] "that authors and readers found piquancy in uncertainty about truth in literary works was perhaps fed by the inescapable uncertainty about truth in documents relied on for order in a monarchical state." 76

In order to delve into the objections raised against the monarchy in the wake of the Saint Bartholomew's Day massacres of 1572 , it will be necessary to reconstruct the

73 Ferguson, Utter Antiquity, 115-116.

74 Kevin Sharpe, Politics and Ideas in Early Stuart England: Essays and Studies (London: Pinter, 1992), 269.

75 Natalie Zemon Davis, Fiction in the Archives: Pardon Tales and their Tellers in Sixteenth-Century France (Stanford: Stanford University Press, 1987), 112-113.

76 ibid., 113. 
framework within which French kingship was perceived in the sixteenth century. Further, an examination of how the origins, rituals, and symbols associated with French kingship changed throughout the Renaissance would serve to provide some context for the post1572 constitutional debates. Despite vocal criticism, these ideas of kingship fostered a sense of patriotism and a spirit of French nationalism that would become institutionalized during the reign of Louis XIV in the succeeding century.

Just as the shield fell from heaven in front of Numa [the second king of Rome, who received a bronze shield from God and saved the city from a plague] divine gifts supposedly came the way of the first Christian king of France, Clovis. On the occasion of his baptism, he was anointed with oil delivered form heaven in a vase by a dove, or by angels; and angels also delivered an oriflamme which displayed the cross of Christ, and an amorial shield displaying three fleur-de-lys, to replace his pagan insignia of three fat toads. ${ }^{77}$

The effort undertaken by humanist scholars in tracing the ancient origins and ancestral lineage of French kings was "in effect tapping into a source of great potential power...[because] Invention, for all the exercise of ingenuity it may involve...[meant that] The inventor has considerable power since the qualities that he finds or releases will forever be inherent in the thing invented."78 The cult of the king that developed at the end of the fifteenth century, and grew to mythic proportions by the early sixteenth, should be seen as one of the ways the French established an image of kingship that was based on a common historical origin.

To a great extent, the propaganda surrounding the Hundred Years War can be seen as laying the cultural foundation upon which the idea of what it meant to be French would be more fully articulated in the context of constitutional crisis of the sixteenth century. That is to say, the quarrel of succession between the Valois and Plantagenet families, in time,

77 Malcom C. Smith, "Opium of the People: Numa Pompilius in the French Renaissance," Bibliotheque d'Humanisme et Renaissance, 52 (1990): 14.

78 Rothstein, "Etymology, Genealogy, and the Immutability of Origins," 335; 345. 
came to be perceived as a battle between France and England—states that were shown to have distinct historical origins. There are two primary components in the anti-English propaganda issued during the period of the Hundred Years War that relate directly to, and appear frequently in the rhetoric of, the constitutional debates of the sixteenth century: the mythical founding of ancient France by the Trojans-which, in the sixteenth century gave way to the myth of Gaul-and the Salic Law.

During the course of the Hundred Years War, the Trojan myth, based on the seventh-century writings of Fredegarius, became the official "truth" upon which to base attacks on the English. In 1328, that myth assured the legitimacy of Philippe de Valois, the French pretender to the throne, against the claims of Edward III. Simply, the legend went as follows: After the destruction of Troy, the Trojan exiles founded the city of Sicambria in what is now Hungary. Then an army, under the leadership of the Trojan prince Francio, defeated the armies of Theodosius, settled in Gaul, and founded the city of Lutetia. According to the legend, two other Trojan princes, Enea and Antenor, went on to found the cities of Rome and Venice. In time, Gaul was renamed France in honor of Francio and its capital, Paris, was named in honor of the Trojan abductor of Helen of Troy. Sometime after 396 A.D., according to the legend, the Franks-descended from Francio's armies-who had settled in Gaul elected their first king, Pharamond. Through Pharamond, the French crown descended to Clodion, Merovech, Childeric and then to Childeric's son, Clovis, the first Christian king of France.

The myth survived in popular consciousness and "histories" well into the fifteenth century, when it was replaced by the myth of the Gauls. As French culture became steeped in these stories, the myth succeeded in defining France within a specific geographic, political, and historical space. However, it has been argued that, "following the legends of Troy and Paris, it remained for France to populate these topoi with individuals who would 
have a shared tradition, a national spirit. The myth of the Gauls (our ancestors, the Gauls) provided for a unity based upon a national mentality."79

Like the myths that surrounded the origins of the Franco-Gallic state, the mythical evocation of the Salic law in 1328 arose as an historical fiction that affixed regulations regarding monarchical lineage and territorial possession to French jurisprudence, as it applied to the succession of the throne. The exploitation of the Salic law by the Valois family came to be understood, by the sixteenth century, as part of an effort to prevent succession of the French throne to the English king, Edward III. None of Philippe Le Bel's three sons-Louis X, Philippe V, and Charles IV-left a direct heir. However his daughter, Isabella, had succeeded in producing a son with her husband, the English king Edward II. Without any direct heirs, Philippe de Valois (a cousin of Charles IV) stepped forward to claim the throne. This presented a grave problem for the French peers, who realized that Isabella's son (Edward III) possessed a legitimate claim to the throne, through direct kinship with the dead king through his mother. Not wanting to cede the crown to the English pretender, Philippe de Valois invoked the Salic law-though it has been shown that the story of Philippe's evocation of the Salic law developed out of an historical myth dating from the fifteenth century. ${ }^{80}$

Despite the findings of twentieth-century scholarship, in the sixteenth century the Salic law was widely regarded as historical "truth" by both sides in the political debates. As it came to be understood, the Salic law had its origins in the traditions of the Franks, who had conquered Gaul from the Romans, and had, since that time, become a part of French law. Simply stated, the Salic law was designed to prevent the inheritance of titles

79 Philippe Desan, "Nationalism and History in France during the Renaissance," Rinascimento, 24 (1984): 279.

80 Ralph E. Giesey, "The Juristic Basis of the Dynastic Right to the French Throne," Transactions of the American Philosophical Society, 51 (1961): 18. 
or property through a female line; ties of kinship passed exclusively through male lineage. Beyond preventing English control of the French throne and its territories, it was understood that Philippe's invocation of the Salic law also ensured that all his male heirs should legitimately succeed the French throne in perpetuity.

In the context of the civil wars of the sixteenth century, questions concerning the nature of the Salic law provided much of the fodder for the political debates that reached a fevered pitch in the wake of Saint Bartholomew's Day 1572. In a clear breach of objective scholarship, François Hotman was so eager to apply the Salic law and other ancient Frankish customs to contemporary circumstances, that he argued "even if no article of the Salic or Frankish Law, by which women were excluded from hereditary right in the kingdom, be extant, nevertheless the practices and customs of the nation have acquired the force of written law." 81 In a thinly disguised attack on the regency of Catherine de Medici, Hotman cited a bevy of historical precedents to demonstrate the ruin brought to a nation any time a women gained control of the throne: "Indeed it has so happened that, if ever women acquired control of the administration of the kingdom in the times of our ancestors, they always caused extraordinary calamities in our commonwealth."82

Even Jean Bodin, who became an uncompromising advocate of strong monarchical control, recognized the importance of the "most ancient laws of the Saliens." 83 In a testament to the power of historical myth, Bodin cited the evocation of the Salic law by Philippe de Valois against the claims of Edward III, when "the general consent of all the senators and princes of France" decreed that "no man in that country should use the

81 Hotman, Francogallia, 399-401.

82 ibid., 483.

83 Jean Bodin, The Six Bookes of a Commonweale [facsimile reprint of the 1606 English translation by Richard Knolles], ed. Kenneth D. McRae (Cambridge, MA: Harvard University Press, 1962), 753-54. 
authority of foreign laws, but that everyman according to his right should interpret the law Salique." 84 Stretching the "truth" of the myth still further, Bodin argued that "this Salique law...was not only alleged and put into practice, in the reign of Philip Valois...but also in the time of Clothaire, Sigebert, and Chidebert, who were all prefered before their predecessor's daughters." 85

Though one should take care in attributing Gallic consciousness to historical consciousness, humanist scholarship during the French Renaissance certainly did give birth to a sense of patriotism in France that one could arguably consider to be an expression of cultural modernity; inasmuch as the political language and iconography of the period should be seen as a demonstration of emerging French nationalism. In this regard, the sixteenth century witnessed the symbolic construction of a spirit of nationalism that would become popularized, and developed into a program for political action, in the eighteenth century.

Statues of Francio and Pharamond, designed to represent the "origins of national union in the founding leaders...that moment when the nation and the monarchy were born," greeted Charles IX from the triumphal arch as he made his entry procession into the city. ${ }^{86}$ The same reverence for the mythical origins of France is found in an inscription of Du Breul's Theatre des antiquitez de Paris, which hung above the statue of Philippe de Valois in the grand nave of the Notre Dame Cathedral in Paris. Part of the inscription reads:

Ainsi l'a sanctionné l'auguste décret de Pharamond; sa gloire exige que la postérité garde à jamais cette loi. Son premier nom Loi Gallique, sans doute afin que cette loi fût particulière aux Gaulois, comme la seul

84 ibid.

85 ibid.

86 Lawrence M. Bryant, The King and the City in the Parisian Royal Entry Ceremony: Politics, Ritual, and Art in the Renaissance (Geneva: Droz, 1986), 130-131. 
convenable à ces coeurs vaillants...Reste longtemps heureuse, ô France, sous le sceptre de ce grand roi qui n'a pas de rival dans l'univers! ${ }^{87}$

In a similar nod to the mythical power his Trojan ancestors, Henri II named his sons Edouard-Alexandre (the future Henri III)-after Paris-Alexandre, who returned Helen to Troy-and François-Hercule (the duc d'Alençon). ${ }^{88}$

Since the mid-fifteenth century, royal entries into the city of Paris were highly choreographed affairs that succeeded in projecting a model of ideal national kingship through symbolism that conveyed the abstract notion of crown rights. ${ }^{89}$ However, in the course of the sixteenth century, it has been shown that "the late medieval portrait of the king as an image of justice (usually shown by a figure representing virtue placed next to the king) was altered to depict the parlementaires' claim that they represented the king in matters of justice. In effect, the parlementaires succeeded in having immortal virtue portrayed as an image of themselves." 90 The not-so-subtle, nor arbitrary, shift in the iconography of the royal entry procession reflects well the increasing interest paid in this period to the role of assemblies of the "people" in the governance of France.

Anticipating a more elaborate formulation by François Hotman and others some years later, President Jean de Selve delivered a speech before the Parlement of Paris in 1527. Maintaining that the relationship between the king and his people was predicated upon the successful discharge of his constitutional obligations, De Selve argued that "...a

87 Desan, "Nationalism and History in France during the Renaissance," 268-269.

88 Rothstein, "Etymology, Genealogy, and the Immutability of Origins," 335.

89 For further reading on royal iconography, see: Ralph E. Giesey, The Royal Funeral Ceremony in Renaissance France (Geneva: Droz, 1960); Victor E. Graham and W. McAllister Johnson, The Paris Entries of Charles IX and Elisabeth of Austria, 1571. With an Analysis of Simon Bouquet's Brefet Sommaire Recueil (Toronto: University of Toronto Press, 1979) and The Royal Tour of France by Charles IX and Catherine de' Medici: Festivals and Entries, 1564-6 (Toronto: University of Toronto Press, 1979).

90 Bryant, The King and the City, 138. 
marriage is made between the said lord [Francis I] and his subjects, and the law of that marriage which the said lord must keep is to uphold and maintain the Laws of his Crown, not the least of which is the Salic Law, which has been maintained over time as a holy and just law and according to which the Laws of the Crown are themselves inalienable..."91

This marriage metaphor was picked up in earnest by Huguenot polemicists in the years after the events of August 1572. Given their objections to the actions of the crown in the course of the civil wars, the metaphorical wedding of the children of France with their royal father, the king, was employed by the Huguenots to demonstrate that a king cannot rule without a people - that "the king is the husband and political spouse of the chose publique, which brings to him at his coronation the domain as the dowry of his crown; and the royal children are children of the French people and of the chose public."92 Huguenot propaganda, too, reinforced the view of the royal father not only as invested with the responsibility of maintaining the public welfare, but created by the people for that very duty. In an essay replete with historical examples designed to demonstrate the problems of contemporary France, François Hotman argued that

the king has the same relationship with the kingdom as a father with his family, a tutor with his student, a guardian with his ward, a pilot with the passengers on ship, a commander with his army. Therefore, just as the pupil is not created for his tutor, nor the ship for the pilot, nor the army for the commander, but on the contrary, all these latter are appointed for the former, so the people are not found and procured for the sake of the king, but rather the king for the people. For there may be a people without a king...[b]ut the idea of a king without a people is inconceivable as a pastor without a flock. 93

91 Hanley, The Lits de Justice of the Kings of France, 83-85.

92 Sarah Hanley, "Engendering the State: Family Formation and State Building in Early Modern France," French Historical Studies, 16 (1989): 26-27.

93 Hotman, Francogallia, 273-275. 
This view was confirmed some years later by the author of an anonymous pamphlet entitled the Vindiciae contra tyrannos. Defending the right of a people to depose a tyrannical king, the author argued that "In a commonwealth, commonly compared to a ship, the king holds the place of a pilot, the people in general are owners of the vessel, obeying the pilot, whilst he is careful of the public good.' 94

94 Junius Brutus [Philippe Duplessis-Mornay], Vindiciae contra tyrannos (Basel, 1578-1579), ed. Harold J. Laski [facsimile of the English translation of 1689] (Gloucester, MA: Peter Smith, 1963), 125. 


\section{CHAPTER 6}

\section{SCHOLARSHIP GIVES WAY TO POLEMIC}

At the heart of this argument was the idea that French kings received their sovereign authority from, and were elected by, the assemblies of the people; kings were not the proprietors of justice, but simply administrators. The writers of this period based their claim upon historical studies of the ancient French constitution, as preserved by the public council of the realm since the time of the Gauls. In his Reserches, Etienne Pasquier represented the Druid assemblies of ancient Gaul (in which the Druid priests settled disputes among their people) as the forerunner of the French parlement. Then, after noting that Clovis had "accommodated himself to prevailing religious and civil observances after conquering Gaul," he identified the moderating power of the ancient Druid assemblies to be manifest in the Carolingian assemblies of his own time. ${ }^{95}$

Similar to Pasquier's anachronistic juxtaposition of ancient Gallican traditions and contemporary assemblies, other writers, too, displayed a willingness to sacrifice historical scholarship to the needs of political polemic. Though François Hotman genuinely believed in the history of the ancient constitution of France, the Francogallia demonstrates the inability of many of the writers of this period to understand the development of French institutions; they understood origin and history, but failed to perceive change over time.

Hotman and others posited the existence of the ancient constitution, which somehow became engendered in Frankish institutions, where, through the public council, it continued to function as a limitation on royal authority through succeeding dynasties until it was subverted by Charles VIII (who refused to recognize the legislative authority of the

95 Schiffman, "An Anatomy of the Historical Revolution in Renaissance France," 528-529. 
Estates-General in 1484). Following this argument to its conclusion, the subversion of the estates during the reign of Charles VIII, by definition, set the stage for the political crises of the sixteenth century. In looking at the Francogallia, some have argued that Hotman "did not apply Frankish practices to the present."96 This is manifestly false. Pressured by contemporary events, the historical studies of Hotman and other writers of like conscience were transformed into, and subsumed by, political polemic advocating the revival of the Estates-General in order to counter the growing absolutism of the monarchy.

In the preface to the Francogallia, Hotman makes it clear that "the most certain remedy for our [France's] great afflictions should be sought in the constitution."97 Hotman then focused his attention upon the history of Frankish institutions, which he believed demonstrated an active participation of the people in the government. This participation, Hotman argued, extended even to the creation of a king. Hotman then proceeded to assemble a covey of historical examples to buffer his, and others', claim that, historically, kingship in France was elective. Thus, because it was the right of the "estates and people to constitute and maintain kings...the supreme power of deposing kings was also that of the people."98 Noting the fifth-century deposition of Childeric by the Franks, Hotman argued that this event was of significant historical importance, "because it was done near the beginning and in the infancy of the monarchy, as if it were a witness and declaration that in Francogallia kings were created by fixed laws and were not constituted as tyrants with unbridled, free and unlimited authority." 99

96 Richard A. Jackson, "Elective Kingship and Consensus Populi in SixteenthCentury France," Journal of Modern History, 64 (1972): 157.

97 Hotman, Francogallia, 143.

98 ibid., 235.

99 ibid., 235-236. 
Though he provides copious reference to a variety of sources to support his case, the employment of these sources is often highly selective and subjective. One might ask whether he consciously chose only those sources which could lend their support to his polemic? By way of example, Hotman discounted the Byzantine historian, Agaithias', view that the sons of Frankish kings customarily succeeded their parents, noting that he had "little knowledge of their ways, being a Greek and a foreigner."100 Instead, Hotman quotes the tenth-century French chronicler, Aimon of Fleury, who showed that "the Franks elected themselves a king according to the customs of other nations, and they placed Pharamond (the first king of the Franks) upon the royal throne."101 Similarly, Hotman cites the coronation of Charles the Bald in 869. Although he grants that Charlemagne "girded his son Charles with the insignia of manhood, that is, with the sword, placed the royal crown on his head...[he still] had to be confirmed by the people."102

However, thorough study of the Carolingian period reveals that Hincmar, the Archbishop of Reims, employed the oil originally used at Clovis' baptism to confer divine grace upon the king. ${ }^{103}$ It has been argued that this procedure was significant, in that it demonstrated "the implicit dropping of any formal election or even pretense to an election procedure."104 Further, Hotman cites Gregory of Tours' description of the election of Clovis, and seems to acknowledge Gregory's description of Clovis' elevation upon a shield by his elector (which "made him king over them") merely as a symbolic gesture:

100 ibid., 243.

101 ibid., 223.

102 ibid., 333-335.

103 It should be noted that it is possible that Hotman did not know about Hicmar or his annointing of Clovis: Hotman, Francogallia, n53.

104 Walter Ullman, The Carolingian Renaissance and the Idea of Kingship (London: Methuen, 1969), 92. 
"This was the custom practiced among our kings."105 In this regard, Hotman succeeds in manipulating his source to fit his needs. Gregory's full account shows that the Franks conferred supreme power on the king above and beyond that of his subjects. When Clovis, seeking a greater portion of the booty than was customarily granted, addressed his men after the surrender of Soissons. To his demands, his men acquiesced, stating that "Everything in front of us is yours, noble King, for our persons are yours to command.

Do exactly as you wish, for there is none among us who has the power to say you nay."106

Further Hotman, citing Charlemagne's Capitularia, claimed that "it is manifest from these words that the people of France were formally bound only by those laws which they had approved by their own votes in the assemblies." However, it has been argued that when Charlemagne succeeded in "harnessing both the Germanic element-the Munt [the idea of protection - and a crucial feature of the ecclesiological theme-that is, divinity conferring the grace (or benefit) of Rulership," he followed this institutionalized conception of kingship with the creation of the law (the Capitularia). Charlemagne's Capitularia, thus, demonstrated the autonomous will of the ruler and the refutation of the belief that the king was bound "by those customs and practices which originated not in any exercise of the Ruler's will, but in the people itself."107

One of the single most influential pieces of Huguenot propaganda that emerged after the Saint Bartholomew's Day massacres of 1572, was a collection of treatises published under the title Mémoires de l'estat de France sous Charles IX. The collection was published by Simon Goulart, who later became Théodore de Bèze's successor in Geneva,

105 Hotman, Francogallia, 233.

106 Gregory of Tours, The History of the Franks, trans. Lewis Thorpe (London: Penguin, 1974), 138.

107 Ullman, The Carolingian Renaissance, 46. 
in five complete editions between 1576-1579. ${ }^{108}$ Contained in the collection were five significant treatises which sought to analyze contemporary circumstances in France, and to supply historically- or theologically-based recommendations for a resolution of the current political crisis. Apart from Hotman's Francogallia, which has already been discussed, Goulart reproduced the entire texts from four other-three of which we will deal with here-previously published treatises for publication in the Mémoires. They include: the anonymous Du droit des magistrats (known to be the work of Théodore de Bèze); another anonymous work entitled Le politique...notable discours de l'authorité des princes et de la liberté des peuples; the anonymous Discours de la servitude volontaire (attributed to Étienne de la Boétie, a friend of Michel de Montaigne); and the most radical of the three, the anonymous Discours politiques des diverses puissances establies de Dieu au monde.

Bèze's $D u$ droit des magistrats bases most of its attack on references drawn from the Old and New Testaments, as well as some passing appeal to the histories of the medieval chroniclers in the style of Hotman's Francogallia. The treatise argues two basic points: any irreligious or iniquitous command issued by a prince must be disobeyed; and inferior magistrates have the right to depose a king. Bèze argues that, because kings receive and hold their power directly from God, they must be obeyed only so long as their decrees are in harmony with divine law and natural law-meaning that they must be both biblically supportable and non-injurious to the relationship between man and his neighbors. If a monarch were to violate either of these precepts, Bèze argued, he could be justifiably deposed-or, under certain circumstances, killed—by lesser magistrates. Drawing on a variety of sources, including the ephors of Sparta, the English Parliament and the Estates-

108 For more on Goulart and the Mémoires, see: Leonard Chester Jones, Simon Goulart, 1543-1628: Etude biographique et bibliographique (Geneva: Georg; Paris: Champion, 1917); Robert M. Kingdon, The Myths about the St. Bartholomew's Day Massacres, 1572-1576 (Cambridge, MA: Harvard University Press, 1988). 
General, Bèze argued that magisterial institutions were created for "the people," like teachers for their students or shepherds for their flocks. ${ }^{109}$ Bèze then goes on to describe the contractual nature of the relationship that existed between ruler and ruled, citing such diverse examples as the coronation oath taken by Aragonese kings--a source also cited in the Francogallia ${ }^{110}$ and the French Estates-General.

Étienne de la Boétie's Discours de la servitude volontaire appeared in Goulart's collection well after the author's death at the end of the first civil war in 1563. Simply, the Discours begins with La Boétie's reflections on why people are willing to live under the rule of a tyrannical government. He then departs on a discussion of the three types of tyrants: those who were elected; those took control by force of arms; and those who gained the throne by inheritance. ${ }^{111}$ Each of the three, for La Boétie, have displayed a penchant for tyranny over the course of history. Discussing the ways in which tyrants maintain their power, given that they are only one man, La Boétie argues that some tyrants deceive the people into believing that they have magical powers. By way of example, he argues that "our own leaders have employed in France certain similar devices, such as toads, fleur-delys, sacred vessels, and standards with flames of gold."112 Though La Boétie does not directly mention the French monarch in the course of his discussion of tyrannical

109 Théodore de Bèze, Du droit des magistrats, ed. Robert M. Kingdon (Geneva: Droz, 1971), 12-14.

110 For more on the history of the Aragonese coronation oath, see: Ralph E. Giesey, If Not, Not: The Oath of the Aragonese and the Legendary Laws of Sobrabe (Princeton: Princeton University Press, 1968); for Hotman's use of the oath, see: François Hotman, Francogallia, 307-309.

111 Étienne de la Boétie, Discourse of Voluntary Servitude, trans. Harry Kurz (Montréal: Black Rose, 1975), 58.

112 ibid., 74. 
governments and the remedy for dislodging them from power, his readers no doubt drew their cue from the actions of Charles IX during the civil wars.

As a curious side-note to the Discours, one can detect La Boétie's acculturation in French humanism in the pride of place he granted to the poets Ronsard, Baif, and Du Bellay. It has been argued that French intellectuals viewed the use of the vernacular as a way in which to further culturally distance France from its classical heritage - taken here to mean Latin and Greek. ${ }^{113}$ La Boétie confirms this view when he argues that French poets "are defending our language so well that I dare to believe that very soon neither the Greeks nor the Latins will in this respect have any advantage over us except possibly that of seniority."114

The most revolutionary of the treatises that appeared in Goulart's collection, was an anonymous tract known, in its abbreviated form, as the Discours politique. The author begins with a two-fold analysis of government: religious and secular. The first analysis concludes with the author stating that, because "all power flows from God, the power exercised by men is of divine origin and all who exercise it are automatically God's servants. Because God is just, furthermore, all power must be exercised with justice; if not, it is no longer legitimate and need not be accepted."115 The author of the Discours then cites references from history to articulate what he views as the best form of government. After looking at the origins and nature of government, and the social organization of society, the author determines that the force that binds the two together is justice-legal and moral. The constitutional precept that underlies the Discours is that "The civic polity (or the state of France) over generations is immortal; its individual citizens are

113 Dubois, Celtes et Gaulois au XVIe siecle, 27.

114 La Boétie, Discourse of Voluntary Servitude, 74.

115 Kingdon, Myths about the St. Bartholomew's Day Massacres, 174. 
not."116 Therefore, citizens of the state must actively pursue the maintenance of the state through force of law. Further, sovereign authority is vested in the whole community-the authority of the king is not as an individual, but as an officeholder-which grants it to the king to insure the public welfare; that grant can be revoked.

Though not included in Goulart's Mémoires, an anonymous tract-though the work has often been attributed to the Huguenot nobleman, Philippe Duplessis-Mornayentitled Vindiciae contra tyrannos (first published in 1579) was of ten included in collections of Huguenot propaganda that circulated at the time. The treatise essentially deals with the four questions that bound the body of Huguenot propaganda at the time: Is obedience to a prince negated if that prince violates the laws of God? Is it lawful to resist a prince who ruins the state? Is it lawful to resist a prince who ruins the Church? Are neighboring princes bound by law to intercede on behalf of subjects who justifiably resist a tyrant? Citing a variety of examples from Scripture and the annals of French and classical history, Duplessis-Mornay, seeking to anticipate attacks on the populist tone of the treatise, argues that

When we speak of all the people [who maintain order in a commonwealth], we understand by that, only those who hold their authority from the people...and whom the people have substituted, or established...to restrain the encroachments of sovereignty, and to represent the whole body of the people. We understand also, the assembly of estates, which is nothing else but an epitome, or brief collection of the kingdom, to whom all public affairs have special and absolute reference. ${ }^{17}$

Further, Duplessis-Mornay's treatise also underscored the contractual relationship that existed between sovereign and subject-which maintained the authority of the people above that of the king--in the elective precepts of the French constitution: "The ancient custom of

116 Sarah Hanley, "The French Constitution Revised: Representative Assemblies and Resistance Right in the Sixteenth Century," in Society and Institutions in Early Modern France, ed. Mack P. Holt (Athens, GA: University of Georgia Press, 1991), 37.

117 Junius Brutus [Philippe Duplessis-Mornay], Vindiciae contra tyrannos, 97. 
the French [the acknowledgment of the power and authority of the elected king] is known exceeding well, for they used to lift him up on a buckler, and salute him whom they had chosen."118

The weakness of Duplessis-Mornay's emphasis on the contractual nature of the ruler-ruled relationship ("a king cannot rule without a people")-and, one could argue, that of his compatriots-rests in his use of the organic metaphor of the body to define the operation of the commonwealth. ${ }^{119}$ It has been argued that the operation of the body is not joined by covenants (contractual relationships). Therefore, "In the same way, when commonwealths already in being were at issue, all possible parties to any putative covenant were already parts of the commonwealth, defined by their relationship to one anther and to the whole, which they were parts. They thus were demonstrably not possessed of the independence and formal equality required of parties to a covenant."120

118 ibid., 125.

119 For the origins and development of this strain of thought, see: Ernst $\mathrm{H}$. Kantorowicz, The King's Two Bodies: A Study in Medieval Political Theology (Princeton: Princeton University Press, 1957).

120 Höpfl and Thompson, "The History of Contract as a Motif in Political Thought," 931. 


\section{CONCLUSION}

In 1576, Jean Bodin argued that "newness in matters of laws is always contemptible, whereas to the contrary, the reverence of antiquity is so great...[t]hat we must not change any thing in the laws of a Commonweale which has long maintained itself in good estate, whatsoever apparent profit thereby pretended."121 Though Bodin sought to rebuff the constitutionalist arguments of Huguenots, he too looked to history "to furnish a proof of his key contention in the Six Books to the effect that an absolute and irresistible sovereign power must by definition exist in any viable state."122 Bodin's attack on Hotman and other writers was based on his belief that they had completely misunderstood the constitutional history of France. Therefore, his "scientific" history of the laws of Commonwealth naturally stood firmly opposed to the confusion of French legal history that had been so vocally articulated by Huguenot political theorists and propagandists.

Bodin's efforts serve to return our study full circle to the claims of the narrator in Rabelais' Gargantua-who, through his scientific research, sought to portray himself as a modern historiographer. Under the influence of humanist legal scholarship, France in the sixteenth century underwent an historical revolution. Humanist legal scholars demonstrated the distinctiveness of French institutions and culture. Through their intensive study of French institutions, laws, and customs they succeeded in undermining any notion of normative legal standards derived from classical antiquity that could be readily applied to contemporary circumstances. As stated previously, the character of a nation's laws, and the ideas that underlie those laws, affects that nation's relationship with its past. With this in mind, the historical revolution that took place in sixteenth-century France "owed perhaps

121 Bodin, The Six Bookes of a Commonweale, 469-470.

122 Skinner, The Foundation of Modern Political Thought, II: 293. 
as much to the 'systemization and codification of existing customary law' as it did to the systematic investigation of the legal heritage of Rome. Views of the medieval past were altered in much the same manner as the classical past, so that it, too, came to be observed from a "fixed distance'."123 Therefore, the ability of legal scholars to demonstrate the relativity of legal standards went hand-in-hand with the questioning of the trans-cultural applicability of political, religious, and social systems that one finds clearly present in sixteenth-century France.

Once the study of French legal history had forced a re-evaluation of Roman and medieval legal traditions, scholars began to question other assumptions that had been made regarding a heretofore assumed shared cultural heritage with classical Rome. Drawing on the influence of humanist juridical exegesis, French historians and antiquaries began to retrace the history of France back to its non-Roman origins in the Franks of ancient Gaul. Their efforts have been shown to be, in great measure, the result of intellectual insecurity. The principle of relativism, which was born out of their historical enterprises, forced sixteenth-century society to seek some sense of order to a world thrown into the intellectual chaos that this unsettling principle necessitated. Therefore, this society sought to construct an image of the past that would serve to provide some context and support to the turmoil of present circumstances. As a result, it was during this period when the historical myths, legends, and customs that comprised the cultural fabric of French society were transformed into new myths that spoke more directly to contemporary life.

Though difficult to measure, there exists a difference between modern historical scholarship and modern historical consciousness. In this paper it has been argued that the struggle to recreate, and indeed return to, France's mythical past did not necessitate an understanding of historical change as an on-going process of development. Though

123 Eisenstein, The Printing Press as an Agent of Change, 200. 
humanist scholarship had succeeded in underscoring the uniqueness of French institutions, customs and the like, the sixteenth-century mind was unable to adequately perceive of changes in these phenomenon over time. For the sixteenth-century, material causation in historical change became increasingly identified with origins. In order to find the "substance" of history, therefore, it was believed that one must seek to discover its origins. History, then, came to be viewed as a storehouse of knowledge that only required classification and organization in order articulate causality.

However, though the world view of the sixteenth century was opened up under the weight of humanist endeavors to seek the origins of the French state within that storehouse of knowledge, it remained conceptually sterile. Despite the fact that French institutions and customs came to be viewed as unique by virtue of their origins and history, writers of this period confused the "unfolding" of these institutions from their ancient origins with a misperception of historical change. Therefore, the natural inclination for a society which was intellectually ill-equipped to understand historical change, was to transpose a perception of the past upon the present. In this regard, an "objective" examination of the past-what one could argue is the foundation upon which "modern" historicism is basedwas subsumed by the needs of the present.

This subsumation of historical "objectivity" to the political crises of the sixteenth century is perhaps no more clearly articulated than in the ironic ideological reversal that occured during the late 1580's and early 1590's. Shocked by the events of the St. Bartholomew's massacre of 1572 , many moderate Catholics rejected the domination of religious zeal in political affairs and were moved to subvert their religious predelictions in the hopes of effecting an end to the bloodshed of the civil wars. Forging a tenuous alliance with the Huguenot leaders Henri de Navarre and Condé (who escaped the massacre of Paris after nominally coverting to Catholicism), the Politique party sought a policy of religious toleration as the only means to peace. At the same time, ultra-Catholics under the 
leadership of Henri de Guise formed the Catholic League, whose stated purpose it was to defend the Church and to extirpate any vestige of Protestantism within France. ${ }^{124}$

As civil war waged between the Huguenot-Politique party and the League between 1577-1584 the new king Henri III (one of the primary instigators of the 1572 massacre in Paris), fearful of the growing power of Guise and the League, became increasingly sympathetic to the Politique cause. Indeed, by the end of his reign, the childless king went so far as to name Henri de Navarre to be his heir to the throne. Henri III's assasination by a Catholic zealot in 1589 led to Navarre's succession as Henri IV. As king, Henri IV also propogated a policy of toleration toward Protestants (the most notable of which was Edict of Nantes, which granted Huguenots a variety of religious and political rights).

The pursuit of a policy of religious toleration and a series of foreign policy blunders led Guise and other ultra-Catholic radicals within the League to articulate calls for armed resistance against the monarchy; calls which were strikingly similar to those espoused by Huguenot polemicists, such as Hotman, Duplessis-Mornay and others, only a few years earlier. In an ironic twist-clearly demonstrative of the aforementioned premise that sixteenth-century Frenchmen readily transposed of a perception of the past upon the political realities of the present-the Catholic League rejected the succession of Henri IV and propogated a policy of just resistance based on many of the historical principles drawn from Huguenot political propoganda in the 1560's. As described in the association's charter, the Leaguers vowed, upon fear of eternal damnation, to restore the "rights, preeminences, franchises and ancient privileges as they were in the time of Clovis, the first Christian king, and inventing even better and more profitable ones, if such be possible,

124 For a thorough treatment of the Catholic League, see: Frederic J. Baumgartner, Radical Reactionaries: The Political Thought of the French Catholic League (Geneva: Droz, 1976) and J.H.M. Salmon, "The Paris Sixteen, 1584-1594: The Social Analysis of a Revolutionary Movement," Journal of Modern History, 64 (1972): 540-76. 
under the protection of the said association."125 As such, the League rejected Henri IV's succession and sought his removal from power, as many argued that the laws of succession were a less fundamental part of the ancient constitution than the catholicity of the crown.

On the other hand vocal Protestant proponents of resistance, such as Hotman and Bèze, turned volte-face and vigorously supported Navarre's claim to the throne; thus alligning themselves with traditional principles of hereditary monarchy. After the League secured Pope Sixtus V's excommunication of Navarre and Condé in 1585-and thus threatening Navarre's rightful inheritance to the throne-Hotman issued a pamphlet entitled Brutum Fulmen, which underscored the primacy of the law of dynastic succession. ${ }^{126}$ In addition, a new version of the Francogallia was issued in 1586, which included historical references, in support of Navarre, designed to appeal to the Gallicanism of the higher clergy and the nobility - who rejected Sixtus' power to depose secular rulers. Bèze also published a set of sermons in 1592, which were critical of the League's plotting against the life of a legitmate monarch. ${ }^{127}$ Indeed, many within the Politique-Huguenot party curiously reversed earlier claims and supported traditional Gallican theories of dynasticism, the divine right of kings and the legislative sovereignty of the monarchy as futher buffers to the challenge to Henri IV posed by the League.

In the final analysis, "objective" historical scholarship was subverted to the needs of political propoganda, in great measure because sixteenth-century Protestants and Catholics alike lacked the ability to explain the origin of the commonwealth or the derivation of the authority of the laws that governed the realm. Instead, they presupposed

125 Hotman, Francogallia, 91.

126 Kelley, François Hotman: A Revolutionary Ordeal, 306-9.

127 Bèze, Du droit des magistrats, 81-4. 
the existence of a body of "fundamental law" from which the king and the officers of the magistracy could claim legitimacy. Unconcerned with "the natural rights of precivil individuals," in the sixteenth century these rights were simply assumed to precede "any particular king or group of lesser magistrates." Bearing this in mind, "assumptions about the existence of an ancient constitution... prevented the articulation of any such evidently conventional, artificial view of the character of civil society. At best, the concept of covenant was useful, because it married reasonably well with the belief in a reciprocity of rights and duties that not even the most determined advocate of monarchial absolutism was disposed to deny." 128 933.

128 Höpfl and Thompson, "The History of Contract as a Motif in Political Thought," 


\section{BIBLIOGRAPHY}

Baker, Keith Michael. Inventing the French Revolution: Essays on French Political Culture in the Eighteenth Century. Cambridge: Cambridge University Press, 1990.

Baumgartner, Frederic J. Radical Reactionaries: The Political Thought of the French Catholic League. Geneva: Droz, 1976.

Benedict, Philip. Rouen during the Wars of Religion. Cambridge: Cambridge University Press, 1981.

Berrong, Richard. Rabelais and Bakhtin: Popular Culture in Gargantua and Pantagruel. Lincoln, NE: University of Nebraska Press, 1991.

Bèze, Théodore de. Du droit des magistrats, ed. Robert M. Kingdon. Geneva: Droz, 1971.

Bodin, Jean. The Six Bookes of a Commonweale [facsimile reprint of the 1606 English translation by Richard Knolles], ed. Kenneth D. McRae. Cambridge, MA: Harvard University Press, 1962.

Brown, Elizabeth A.R., ed. Jean du Tillet and the French Wars of Religion: Five Tracts, 1562-1569. Binghamton, NY: Center for Medieval and Early Renaissance Studies, 1994.

Brutus, Junius [Philippe Duplessis-Mornay]. Vindiciae contra tyrannos...[reprint of the 1689 English translation by Robert Baldwin], ed. Harold J. Laski. Gloucester, MA: Peter Smith, 1963.

Bryant, Lawrence M. The King and the City in the Parisian Royal Entry Ceremony: Politics, Ritual, and Art in the Renaissance. Geneva: Droz, 1986.

Canary, Robert and Henry Kozicki, eds. The Writing of History: Literary Form and Historical Understanding. Madison, WI: University of Wisconsin Press, 1978.

Chrisman, Miriam Usher. Lay Culture, Learned Culture: Books and Social Change in Strasbourg, 1480-1599.

Commynes, Philippe de. Mémoires, ed. Samuel Kinser, trans. Isabelle Cazeaux, 2 vols. Columbia, SC: University of South Carolina Press, 1969.

Crouzet, Denis. Les guerriers de Dieu: La violence au temps des troubles de religion, vers 1525-vers 1610, 2 vols. Seyssel: Champ Vallon, 1990).

Davies, Joan. "Persecution and Protestantism: Toulouse, 1562-1575." Historical Journal, 22 (1979): 31-51.

Davis, Natalie Zemon. Society and Culture in Early Modern France. Stanford: Stanford University Press, 1975. 
- Fiction in the Archives: Pardon Tales and their Tellers in Sixteenth-Century France. Stanford: Stanford University Press, 1987.

Desan, Philippe. "Nationalism and History in France during the Renaissance." Rinascimento, 24 (1984): 261-288,

Dewald, Jonathan. Aristocratic Experience and the Origins of Modern Culture: France, 1570-1715. Berkeley: University of California Press, 1993.

Diefendorf, Barbara. Paris City Coucillors in the Sixteenth Century: The Politics of Patrimony. Princeton: Princeton University Press, 1983.

- Beneath the Cross: Catholics and Huguenots in Sixteenth-Century Paris. Oxford: Oxford University Press, 1991.

- "Prologue to a Massacre: Popular Unrest in Paris, 1570-1572." American Historical Review, 90 (1985): 1067-1091.

Dickens, A.G. and John Tonkin, eds. The Reformation in Historical Thought. Cambridge, MA: Harvard University Press, 1985.

Dubois, Claude-Gilbert. Celtes et Gaulois au XVI ${ }^{e}$ siecle, le developpement littéraire d'un myth nationaliste. Paris: Jurin, 1972.

- La Conception de l' Histoire en France au XVIe siècle (1560-1610). Paris: Nizet, 1977.

Eisenstein, Elizabeth. The Printing Press as an Agent of Change: Communications and Transformations in Early-Modern Europe, 2 vols. Cambridge: Cambridge University Press, 1979.

Ferguson, Arthur B. Utter Antiquity: Perception of Prehistory in Renaissance England. Durham, NC: Duke University Press, 1993.

Foucault, Michel. The Archeology of Knowledge, trans. Allen Sheridan Smith. New York: Harper and Row, 1972.

- "Politics and the Study of Discourse." In The Foucault Effect: Studies in Governmentality, with two lectures and an interview with Michel Foucault, ed. Graham Burchell, Colin Gordon, and Peter Miller. Chicago: University of Chicago Press, 1991.

Galpern, A.N. The Religions of the People in Sixteenth-Century Champagne. Cambridge, MA: Harvard University Press, 1976.

Geertz, Clifford. The Interpretation of Cultures. New York: Basic Books, 1973.

Giesey, Ralph E. "When and Why Hotman Wrote the Francogallia." Bibliotheque d'Humanism et Renaissance, 29 (1967): 581-611. 
- "The Juristic Basis of the Dynastic Right to the French Throne." Transactions of the American Philosophical Society, 51 (1961): 1-47.

- The Royal Funeral Ceremony in Renaissance France. Geneva: Droz, 1960.

-If Not, Not: The Oath of the Aragonese and the Legendary Laws of Sobrabe. Princeton: Princeton University Press, 1968.

Ginzburg, Carlo. The Cheese and the Worms: The Cosmos of a Sixteenth-Century Miller, trans. John and Anne Tedeschi. Baltimore: Johns Hopkins University Press, 1980.

Graham, Victor E. and W. McAllister Johnson. The Paris Entries of Charles IX and Elisabeth of Austria, 1571. With an Analysis of Simon Bouquet's Bref et Sommaire Recueil. Toronto: Toronto University Press, 1979.

- The Royal Tour of France by Charles IX and Catherine de' Medici: Festivals and Entries, 1564-6.

Gray, Janet G. "The Origin of the Word Huguenot." Sixteenth Century Journal, 14 (1983): 349-359.

Halbwachs, Maurice. On Collective Memory, trans. Lewis A. Coser. Chicago: University of Chicago Press, 1992.

Hanley, Sarah. The Lit de Justice of the Kings of France: Constitutional Ideology in Legend, Ritual, and Discourse. Princeton: Princeton University Press, 1983.

- "Engendering the State: Family Formation and State Building in Early Modern France." French Historical Studies, 16 (1989): 4-27.

- "The French Constitution Revised: Representative Assemblies and Resistance Right in the Sixteenth Century." In Society and Institutions in Early Modern France, ed. Mack P. Holt. Athens, GA: University of Georgia Press, 1991.

Harding, Robert R. Anatomy of a Power Elite: The Provincial Governors in Early Modern France. New Haven: Yale University Press, 1978.

Hobsbawm, E.J. "The Social Function of the Past: Some Questions." Past and Present, 55 (1972): 3-17.

Höpfl, Harro. The Christian Polity of John Calvin. Cambridge: Cambridge University Press, 1982.

- and Martyn P. Thompson. "The History of Contract as a Motif in Political Thought." American Historical Review, 84 (1979): 919-944.

Hotman, François. Francogallia, Latin text by Ralph E. Giesey, trans. J.H.M. Salmon. Cambridge: Cambridge University Press, 1972. 
- Le Tigre de 1560, ed. Charles Read. (Paris, 1875); reprinted Geneva: Slatkine, 1970.

Huppert, George. The Idea of Perfect History: Historical Erudition and Historical Philosophy in Renaissance France. Urbana, IL: University of Illinois Press, 1970.

Jackson, Richard A. "Elective Kinship and Consensus Populi in Sixteenth-Century France." Journal of Modern History, 64 (1972): 155-171.

Jones, Leonard Chester. Simon Goulart, 1543-1628: Etude biographique et bibliographique. Geneva: Georg; Paris: Champion, 1917.

Kantorowicz, Ernst H. The King's Two Bodies: A Study in Medieval Political Theology. Princeton: Princeton University Press, 1957.

Kelley, Donald. François Hotman: A Revolutionary Ordeal. Princeton: Princeton University Press, 1973.

- The Beginning of Ideology: Consciousness and Society in the French Renaissance. Cambridge: Cambridge University Press, 1981.

- "Jean du Tillet, Archivist and Antiquary." Journal of Modern History, 38 (1966): 337-354.

- "Martyrs, Myths, and the Massacre: The Background of St. Bartholomew." American Historical Review, 77 (1972): 1323-1342.

- Foundations of Modern Historical Scholarship: Language, Law, and History in the French Renaissance. New York: Columbia University Press, 1970.

Kettering, Sharon. "Patronage in Early Modern France." French Historical Studies, 17 (1992): 839-862.

Kim, Seong-Hak. "The Chancellor's Crusade: Michel de l'Hôpital and the Parlement of Paris." French History, 7 (1993): 1-29.

Kingdon, Robert M. Myths about the St. Bartholomew's Day Massacres, 1572-1576. Cambridge, MA: Harvard University Press, 1988.

La Boétie, Étienne de. Discourse of Voluntary Servitude, trans. Harry Kurz. Montréal: Black Rose, 1975.

Ladurie, Emmanuel Le Roy. Carnival in Romans, trans. Mary Feeney. New York: George Braziller, 1979.

Lambert, Gustave. Histoire des guerres de religion en Provence, 1530-1598, 2 vols. Nyon, 1972.

Montaigne, Michel de. Complete Works, trans. Donald Frame. Stanford: Stanford University Press, 1957. 
Mousnier, Roland. La Vénalité des ofices sous Henri IV et Louis XIII, 2nd. ed. New York: Columbia University Press, 1971.

Neuschal, Kristen B. Word of Honor: Interpreting Noble Culture in Sixteenth-Century France. Ithaca: Cornell University Press, 1989.

Ozment, Steven E. The Reformation in the Cities: The Appeal of Protestantism to Sixteenth-Century Germany and Switzerland. New Haven: Yale University Press, 1975.

Pocock, J.G.A. The Ancient Constitution and the Feudal Law: A Study of English Historical Thought in the Seventeenth Century, 2nd ed. Cambridge: Cambridge University Press, 1987.

Rigolot, François. "Writing the Crisis Differently: Ronsard's Discours and Montaigne's Essais." In Humanism in Crisis: The Decline of the French Renaissance, ed. Philippe Desan. Ann Arbor: University of Michigan Press, 1991.

Roelker, Nancy L. "The Appeal of Calvinism to French Noblewomen in the Sixteenth Century." Journal of Interdisciplinary History, 2 (1972): 391-418.

- Queen of Navarre: Jeanne d'Albret, 1528-1572. Cambridge, MA: Harvard University Press, 1968.

Rothstein, Marian. "Etymology, Genealogy, and the Immutability of Origins." Renaissance Quarterly, 43 (1990): 332-347.

Salmon, J.H.M. Society in Crisis: France in the Sixteenth Century. London: Methuen, 1975.

- "The Paris Sixteen, 1584-1594: The Social Analysis of a Revolutionary Movement." Journal of Modern History, 64 (1972): 540-76.

Schiffman, Zachary S. "Humanism and the Problem of Relativism." In Humanism in Crisis: The Decline of the French Renaissance, ed. Philippe Desan. Ann Arbor: University of Michigan Press, 1991.

- "Renaissance Historicism Reconsidered." History and Theory, 24 (1985): 170182.

Schutz, A.H. Vernacular Books in Parisian Private Libraries of the Sixteenth Century According to the Notorial Inventories. Chapel Hill: University of North Carolina Press, 1955.

Seyssel, Claude de. The Monarchy of France, trans. J.H. Hexter, ed. Donald Kelley. New Haven: Yale University Press, 1981.

Sharpe, Kevin. Politics and Ideas in Early Stuart England: Essays and Studies. London: Pinter, 1992. 
Skinner, Quentin. The Foundation of Modern Political Thought, 2 vols. Cambridge: Cambridge University Press, 1978.

Sleidan, Johann. Apology for His History. In Versions of History from Antiquity to the Enlightenment, ed. Donald Kelley. New Haven: Yale University Press, 1991.

Smith, Malcom C. "Opium of the People: Numa Pompilius in the French Renaissance." Bibliotheque d'Humanisme et Renaissance, 52 (1990): 7-21.

Tacitus, Cornelius. The Complete Works of Tacitus, trans. Alfred J. Church and William J. Brodribb. New York: Modern Library, 1942.

Tierney, Brian. Foundations of Conciliar Theory. Cambridge: Cambridge University Press, 1955.

Tours, Gregory of. The History of the Franks, trans. Lewis Thorpe. London: Penguin, 1974.

Ullman, Walter. The Carolingian Renaissance and the Idea of Kingship. London: Methuen, 1969.

Vivanti, Corrado. "Paulus Aemilius Gallis condidit historias?" Annales: Economies, sociétés, civilisations, 19 (1964): 1117-1124.

Watt, Tessa. Cheap Print and Popular Piety, 1550-1640. Cambridge: Cambridge University Press, 1991. 